\title{
THE BEGINNINGS OF PARTIBLE INHERITANCE IN THE AMERICAN COLONIES
}

\author{
GEORGE L. HASKINS $\dagger$
}

I.

THOMAS Jefferson's attack on primogeniture in $1776^{1}$ is generally considered to have led the way in America for the laws abolishing the descent of fee simple estates to the eldest son. Under these statutes for well over a hundred years the rule has prevailed in the United States that when a person dies intestate, seised of real property in fee simple, such property descends equally to his or her children, subject to the rights of the surviving spouse. Variations appear with respect to succession by the next of kin according to the state statutes of distribution, but among children entitled the general principle of equality of division is preserved. As a recent writer has said, the attitude of this country "may be attributed to the social philosophy in the colonies, and an experience which has been universally unfavorable to the preservation of primogeniture.":

In some of the American colonies, however, opposition to the English rule of primogeniture considerably antedated the Jeffersonian offensive of the late eighteenth century. ${ }^{3}$ In the early New England colonies, and in Pennsylvania, partible descent was observed, as a result both of custom and enactment, from the seventeenth century on. ${ }^{4}$ The practice may be

$\dagger$ Member, The Society of Fellows, Harvard University, 1936 to date.

1. 1 JeFFERSON, WrITINGS (Washington's ed., 1853) 43, 139.

2. Morris, Primogentiture and Entailed Estates in America (1927) 27 CoL. L. Rev. 24.

3. Criticism of the English rule, for example, is found in tracts for the purpose of attracting settlers to New Jersey. See Whiteheid, EAST JerseY Under the PropkiEtary Governments (2d ed. 1875) 324, 389; Morrts, Studies in the History of AmerICAN LAW (1930) 77-78. For criticism of primogeniture in England itself, see note 255 infra.

4. These colonies-Pennsylvania, Connecticut, Plymouth and Massachusetts Bayprovided for divisible descent, with a double portion reserved to the eldest son. In the eighteenth century it is also found in Delaware. 1 DeL. Body Laws 1700-1749 (1752) 297, 298. In Rhode Island both primogeniture and divisible descent were in force, at different times. Morris, op. cit. supra note 3, at 78, states that except for the ycars 1718 to 1728 land descended to the eldest son. See 4 R. I. Col. Reconos (1859) 238, 417; R. I. CoL. Laws (1719) 95, 96. There seems to be some reason to question this. In 1647 it was enacted "that in case a man dyeth intestate . . . they shall make an equal and just distribution of his Estate among those to whom it does belong." $1 \mathrm{R}$. I. Cot. Records (1859) 189-190. In 1667 the Council of the Town of Providence is found making a provision for equal distribution. 1 EArLx Records of the Town of Providencl: (1892) 30-34. There is also a suggestion that the large estates in the Narragansett area descended partibly. Channing, The Narragansett Planters, in 4 Jonns Horkins Studies in Historical and Political Science (1886) 16. Further material may be 
traced first to Massachusetts, where, in the colonies of Plymouth and Massachusetts Bay, an intestate's property descended in this way from the time of the earliest settlements. Throughout the colonial period the law provided, subject to the claims of dower and creditors' rights, for equal division among the children, with a double portion to the eldest son.

It is thus apparent that equal descent of realty among an intestate's children in this country has a dual origin. On the one hand it is to be traced, particularly in the southern colonies, to the Jeffersonian offensive and the influence of the back-country party; on the other hand, in New England and Pennsylvania, it is to be traced to the early practices in seventeenth-century Massachusetts. ${ }^{6}$ For this reason the sources of partible inheritance in Massachusetts deserve investigation. Their study will aid, moreover, in shedding light on the growth of an indigenous law of probate in the United States. This mode of descent developed early in the Massachusetts colony among relatively homogeneous groups of people and preceded by well over a century the general opposition to primogeniture; thus its growth has a considerable significance in the legal and social history of the seventeenth century.

The earliest indication of the existence of partible inheritance uf land in the American colonies is found in the colony of Plymouth. In 1627, Isaak de Rasieres, then Acting-Secretary of New Netherland, visited Plymouth, ${ }^{7}$ and observed that "in inheritances they place all the children in one degree, only the eldest son has an acknowledgement for his seniority of birth." 8 Fourteen years later in the neighboring colony of Massachusetts Bay a similar custom was given recognition in two provisions in the Body of Liberties of 1641. In Articles 81 and 82 it is enacted that

found in Eaton, The Development of the Judicial System in Rhode Islasd (1905) 14 YAIE L. J. 148, 158.

For New Hampshire, see Monns, op. cit. supra note 3, at 103 n. 2, 115.

5. Thus, Georgia in 1777, 19 G.. CoL. Reconss (1912), pt. 2, 455; North Carulina in 1784, 24 N. C. State Records (1905) 572-577; Virginia in 1785, 12 VA. Stat. AT LARGE (Hening, 1S23) 146; Maryland and New York in 1786, 2 Mrn. Laws (Mascey, 1871) 16, 1 N. Y. Laws (Greenleaf, 1792) 206; and South Carolina in 1791, 5 S. C. Stat. at LaRge (1839) 162.

6. Massachusetts disposed of its vestigial suggestion of primogeniture, i.c., the duuble portion, in 1789. Acts and Resolves, 178S-1789 (May Session), in 1 Acts arid Luws of the Conronowealte of MAss. (1894) 395-396. New Hampshire followed suit in the same year; 5 N. H. Laws (1916) 384; Pennsylvania in 1794: 15 PA. Stis. AT LARGE (1911) 83; Rhode Island in 179S: R. I. Laws (1798) 287. These statutes were not completely effectual in abolishing primogeniture, since in some jurisdictions today entailed estates descend to the eldest son. This persistence of primogeniture is discussud in relation to its historical background by Morris, loc. cit. suspu note 2. As tu yrimggeniture in entails in Massachusetts, see note 68 infro.

7. 2 Bradford, History of Plymouth Plunramen (Furd's ed. 1913) 41-43

8. In a letter to Samuel Bloomaert, one of the directors of the V'est India Company. 2 N. Y. Hist. Soc. CoLl. 2d Ser. (1849) 339, 352. 
When parents dye intestate, the Elder sonne shall have a doble portion of his whole estate reall and personall, unlesse the Generall Court upon just cause alleadged shall Judge otherwise.?

When parents dye intestate haveing noe heires males of their bodies their Daughters shall inherit as copartners, unles the Generall Court upon just reason shall judge otherwise. ${ }^{10}$

How much before 1641 the practice had made its appearance in the Bay Colony the records do not tell. In one or two instances it is plain that each child took something, though in what ptoportions is not clear. ${ }^{11}$ The early entries as to administrations are very brief, ${ }^{12}$ and it is sometimes even difficult to tell whether the deceased left a will or died intestate. It may well be that the Plymouth experience was drawn upon in the Massachusetts codification. ${ }^{13}$ But in any case it is plain that the simple provision in the Body of Liberties formed the basis for the interpretation in the courts, and for later more elaborate acts.

Although Plymouth colony was founded first and had an intestacy law similar in many respects to that of Massachusetts Bay, the latter has been chosen for study because the records are more accessible and the picture we can form is consequently more complete. ${ }^{14}$ The period selected for study are the years from the founding of the Bay Colony in 1630 to the establishment of the Province of Massachusetts Bay in 1691, for during this time the chief features of the law of partible inheritance were worked out and may best be seen in operation. ${ }^{15}$ No attempt will be made to pursue all the details of the colonial intestacy law, except insofar as is necessary to explain the subject at hand.

Sources for the study are to be found partly in the enactments of the colony, and partly in the interpretation and application of these laws in the records of the courts having jurisdiction in testamentary matters. The former include the acts of the General Court of the Colony $;{ }^{16}$ the latter, generally speaking, the records and proceedings of

9. Mass. Coc. Laws 1660-1672 (1889) 51, c. 81.

10. Id. at $51, \mathrm{c} .82$.

11. 2 Records of the Court of Assistants (1904) 51 (1634-35), 54 (1635); 1 EsSEX Prob. RECoRdS (1916) 11.

12. Ibid., and see note 17 infra.

13. Several achievements of Plymouth seem to have been taken over by Massachusetts Bay-for example, Congregationalism, the recording of 'deeds, the device of codification. See Haskins, The Beginnings of the Recording Systcm in Massachusctls (1941) 21 B. U. L. Rev. 281,285 n. 19.

14. The Plymouth intestacy law from the founding of the colony until its coalcs" cence with Massachusetts Bay in 1691 has been reserved for treatment elsewhere. Its possible influence on the Massachusetts intestacy law has not, however, been overlooked. See Part II infra.

15. The changes during the brief period of the Andros administration, 1686 and following, have not been given special attention.

16. These enactments are to be found in 1-5 RECORDS of MASs. (Shurtleff's ed. 18531854); Mass. Cor. Laws 1660-1672 (Whitmore's ed. 1889); Mass. Col. Laws 1672- 
the county courts. ${ }^{17}$ The colonial laws cannot be considered independently of the court records, since the legislative and judicial functions were really undifferentiated. For, although the county courts were judicial tribunals in name, in a sense they also made law; and conversely, like the assemblies in other colonies, the General Court (the forerunner of the modern legislature) included in its business much that we should today call judicial. Since the seventeenth-century records thus show a fusion of powers entirely characteristic of the day, it should be no cause for surprise when we find the lower courts administering estates in ways unsanctioned by legislative act. Indeed, with regard to several aspects of the law of descent, the enactment by the General Court merely crystallizes existing practices in the county courts.

Attention has been focused particularly on the courts of the seaboard counties of Essex and Suffolk, although other localities have not been neglected. This is partly because many of the records here are available in print, partly because, due to their greater wealth and population, these counties present during the early period of the colony's history more material than the counties to the north and west. ${ }^{18}$ It should be stated, however, that the operation of the intestacy law in Essex and Suffolk is entirely typical of the courts elsewhere in the Bay Colony. ${ }^{19}$

1686 (Whitmore's ed. 1887); and Laws and Lmertres of Misss. (Farrand's ed. 1929). English statutes of the period are not an important source, as will appear.

17. For reasons stated below most of the material used in this study is based on the records of the county and probate courts of Essex and Suffolls.

The Suffolk County Court records survive in two manuseript volumes. One, covering the years 1680-1692, is in a bad state of preservation and is in the office of the Clerl: of the Superior Court of Suffolk County. The other, covering the years 1671-1680, is preserved in the Library of the Boston Athenaeum; most of it has been printcd in Rciords of the Suffolk County Court 1671-1680 (hereafter cited Suffolls Comnly Rccords) in 29, 30 MAss. COL. Scc. COLL. (1933). This material must be sumplemented by the Suffolk Files (hereafter cited S. F.), preserved in the office of the Clerl of the Supreme Judicial Court of Suffolk County, and by the early records and inventories of the Suifolk Probate Court (hereafter cited Suffolk Prob. Records).

Most of the material relating to probate matters in Essex County from 1635-16s1 has been collected in 1-3 Essex Prob. Reconds (1916-1920), or may be found fassin in the Collections of the Essex Institute.

Appeals from the county courts are in general to be found in 1-3 Recusbs of rue Court of Assistaxts (1901-1928), and 1-5 Reconos of MIass. supra note 16.

18. Suffolk, for example, by an act of 1643 , embraced the towns of Boston (including what is now Brookline, Chelsea, Revere and Winthrop), Rosbury, Dorchester, Dedham, Weymouth, Hingham, Braintree, Nantasket (Hull). 2 Retones of MI.sss. 3s. By 1680 it included many more towns in what is today Norfolk County. Essex included, by the same act, Salem, Lynn, Ipswich, Rowley, Newbury and Glousester. To the nurth was old Norfolk County, comprising Salisbury, Hampton. Haverhill, Eseter and Daver; slightly to the west was Middlesex, comprising Charlestown, Cambridge, Watertown, Sudbury, Concord, Woburn, Medford and Reading.

19. For example, the probate and administration proceedings in the records of Mliddlesex County are very similar to those of Suffoll. See Pupers in Cases Bcfore the Conn- 
A major obstacle, however, to effective investigation in this, as in other branches of colonial law, is the manner in which many of the printed records have been edited. ${ }^{20}$ Genealogy, names of persons, inventories have loomed large in the eyes of the compilers, so that the details of administrations, formalities of wills and other valuable data are often omitted. ${ }^{21}$ Moreover, in other cases, the records themselves are all too brief in their information.

Before proceeding to a description of the intestacy law, something more must be said of the courts which had jurisdiction in testamentary matters. Unlike the prevailing practice in contemporary England, where such causes belonged to the ecclesiastical courts, the administration of estates was handled in secular courts. Although probate jurisdiction was not conferred on any court by any colony charter until $1691,{ }^{32}$ it had been assumed almost at once by the General Court, and by the Court of Assistants, ${ }^{24}$ where it remained until the establishment of the first county courts of $1635 / 36$. Shortly thereafter the county courts had begun to take over probate jurisdiction, and in the 1640's the county court became the normal tribunal for such matters. This power was confirmed by enactment of the General Court ${ }^{25}$ which by a law of 1649 ordered that

. . . when the husband or parents dy intestate, the County Court of that Jurisdiction, where the party had his last Residence, shall have power to assigne to the Widdow such a part of his estate as

ty Court of Middlesex Connty, 1649-1663 (unpublished photostatic copy in Harvard Law School Library) 355, no. 837; 487-493, nos. $1181-1183$; 494-495, no. 1186; 620-622, nos. 1517-1518; 646-647, no. 1582. See also the unpublished manuscript Notebook of Walter Pynchon, a magistrate of Agawam (Springfield). Even here, in frontier Massnchitsetts, the process of collecting inventories, granting administrations, etc., is very like the practices in the counties to the East. See, c.g., Notebook 16 (1641), 18-19 (1641), 68 (1654-55), 80 (1659). The manuscript is in the Harvard Law School Library.

20. Notable exceptions are the Reconds of Mass., supra note 16; Reconds of Tut Assistants, supra note 17 ; Records of the Suffolk County Court, supra note 17.

21. Even the three volumes of the ESSEx Prob. Records, supra note 17, are open to this criticism. More flagrant are the omissions in 3, 4, 5, 40, 41 ESSEX INST. Hrst. Coll. (1861-1905) ; 1, 5, 6, 7 Putnam's Monthly Hist. Mag. (1892-1899); 4 ESSEX ANTIQUARIAN (1900). All these contain extracts of wills or administrations which would be of value if only the record had been fully copied. Professor Goebel has recently commented on some of the unfortunate results in entrusting legal research to laymen. Book Review (1938) 43 Amer. Hist. Rev. 403, 404-405.

22. 3 Thorpe, Federal and State Constitutions (1909) 1870, 1881.

23. Examples may be found in 1 Records of MAss. (1853) 151, 153, 259, 278-279.

24. See 2 Records of the Assistants (1904) 34, 35, 46, 51, 52, 55, 56, 57, 58, 59, $72,74,77,81,85$, etc.

25. For dower, in 1647, see Laws and Liberties of MASs. (1929) 17-18; gencrally, in 1649, see 2 Reconds of Mass. (1853) 281, 3 id. at 170; MAss. CoL. LAws 1660-1672 (1889) 200-201. These powers were greatly extended in 1685. See MAss. CoL. Laws 1672-1686 (1887) 122-123. 
they shall judg just \& equal, as also to divide and assigne to the Children or other heires their severall parts and portions out of the said estate. . . ${ }^{26}$

Thus it was to the county court that the executor or the next of kin had to go to present the inventory of the deceased's lands and goods. It was here that the validity of the will was tested, the absence of one shown; here that the division of the property was made, subject to the considerable discretion which rested with the court. ${ }^{27}$ An appeal would lie to the Court of Assistants in cases where "any person shall finde himselfe greived" with the decision of the county court. ${ }^{25}$ That court also had original jurisdiction in at least one case, namely in a matter of dower where the deceased's land lay in more than one county..$^{90}$ On particularly difficult questions, an appeal would lie to the General Court, either directly from the county court, or by way of the Court of Assistants. ${ }^{30}$ The General Court had original jurisdiction at least in cases to relieve a widow who had not been left a competent portion, ${ }^{31}$ or to vary the extent of the shares of the children in instances of hardship. ${ }^{32}$ As will appear, however, these matters were generally taken care of under the broad discretion enjoyed by the county court. ${ }^{33}$

When a person died intestate it was the duty of the next of lin or near friend to give notice of the decease to the county court within one month. A schedule of fines adjusted the penalty for not doing so according to the length of the delay. ${ }^{34}$ Administration would then be granted by the court, usually to the surviving spouse, next of kin, or near friend of the deceased. Severe fines were meted out to administrators for delay in bringing in the inventory; $;^{35}$ and an administrator

26. Mass. Col. Laws 1660-1672 (1889) 201, c. 3. Sce also 2, 3 Reconos of MLiss. (1853), loc. cit. supra note 25. Administration might be granted of the estates of "morchants, seamen and other strangers" dying within the county before any two of the magistrates of the court. 3 Reconds of MLAss. (1853) 280-281; M.1ss. Cot. Luws 1660-1672 (1889) 201, c. 2.

27. This flexibility seems to have been assumed as a delcgation from the Gensral Court under cc. 81 and 82 of the Body of Liberties. Mass. Cor. Laws 1660-16r2 (1899) 51.

2S. 1 Recongs of MLASS. (1853) 169 (in 1635/36), 238 (in 1638).

29. Laws and LIberties of Miass. (1929) is (1647); Misss. CoL. Laws 1660-1672

(1889) 146. For examples, see 3 Records of tHE Assistants (1904) 90-93, 208.

30. E.g., a will made by a minor. 2 Recorps of Ml.sss. (1853) 183. See also 2 id. at 266 .

31. Body of Liberties of 1641 , in MLass. CoL. L.1ws $1600-1672$ (1889) 51, c. 79.

32. Id. at $51, \mathrm{cc} .81-82$.

33. See note 27 supra.

34. 2 RECORAS OF MASS. (1853) 287-288.

35. 2 id. at 287 (1649); Mass. CoL. Laws lo6t0-1672 (1899) 200-201, c. 1. Thro are several cases in which the widow entered on the inheritance in this way before the estate was settled. See "Reasons for Appeal" in Suffoll: Files $470 / 4$. 
who was found to have sold or "embezzled" any lands or goods before submitting the inventory was, in addition, held personally liable for the debts of the estate. ${ }^{36}$ The last two provisions, to judge from the preamble, were enacted in the interest of creditors, who seem to have suffered from the concealment or non-recording of wills and inventories. ${ }^{37}$

The early courts evinced great anxiety to avoid when possible having recourse to the intestacy law, and in all cases of possible intestacy they made every effort to discover the intent, or presumed intent, of the deceased and to administer the estate accordingly. There was a notable lack of insistence on formalities. In fact no formalities of execution seem to have been prescribed by law, and nuncupative wills were allowed freely. Unhampered by the English Statute of Frauds ${ }^{\text {ss }}$ or the Statute of Distribution, ${ }^{39}$ the courts could and did look to the deceased's intent and interpreted his will accordingly.

Intestacy resulted in seventeenth-century Massachusetts when a person died (1) leaving a will defective as to some formality of execution, (2) leaving a will without naming an executor, (3) leaving a will which disposed of a part only of the estate, (4) without leaving a will. It is at once apparent with regard to the formalities of executing a will that the sections of the colonial laws concerned with wills say nothing as to whether wills must be in writing or signed or witnessed. .0 $^{\mathbf{0}}$ It is not strange, therefore, to find so little insistence by the court on such formalities. Several Essex wills, allowed by the court, are unsigned; ${ }^{41}$ at least two in Suffolk are unwitnessed ; ${ }^{2}$ and many others have from one to four witnesses. ${ }^{43}$ Unwitnessed codicils are occasionally tacked

36. 2 Records of Mass. (1853) 287 ; Mass. Col. Laws 1660-1672 (1889) 201.

37. "Whereas it is found by two often experience, that, some men dying and making wills, sajd wills are concealled, \& not prooved \& recorded, \&, others dying intestate, no administration is sought for nor granted, and yet, in either case, the wiues, children, kindred, or freinds of the deceased, or some other, doe enter vpon the lands, \& possess themselues of the goods, of the sajd deceased, \& the same are many times sould or wasted, before any creditor to whom the decease was jndebted know of whom to demand, or how to recouer, their just debts, for prevention of such vnjust \& fraudulent dealings . . . ." 2 RECORDS OF MASS. (1853) 287.

The recording of wills, administrations and inventories was first ordered in 1639 . 1 Records of Mass. (1853) 276. Apparently ineffective, the order was reenacted in $1643 / 44$, with penalties attached for non-compliance. 2 id. at 59.

38. 29 CAR. II, c. $3 \$ 5$ (1677).

39. $22 \& 23$ CAR. II, c. 10 (1670). These statutes were applicable in the colonics only so far as accepted.

40. Mass. Col. Laws 1660-1672 (1889) 35, 121, 140, 200-201; Mass. Coz. LAws 1672 1686 (1887) 32, 157-158.

41. 2 Essex Prob. Records (1916) 81, 90, 122, 190, 242, etc. 1 Suffoll Prob. Records 210-211. A study of the original wills might, however, show that more wills were signed than the probate records indicate.

42. 1 Suffolk County Records 132-133, 230-231.

43. One witness: 1 Suffolk Prob. Records 409, 1 Suffolk County Records 429; four witnesses: 2 id. at 1033 . 
onto the end of a will, ${ }^{4}$ and changes in the will itself are sometimes made merely by blotting out a line. ${ }^{45}$ Very often a seal was attached after the signature, ${ }^{46}$ but its presence or absence seems not to have affected the validity of the instrument. ${ }^{47}$ Such formalities as were observed, in other words, were far from being uniform or consistent. Capacity to make a will was construed somewhat less liberally, for infants were excluded $;^{48}$ but there was no prohibition against women's wills, ${ }^{49}$ although in one case the consent of a woman's husband is mentioned.50

In short, the courts seem to have been little interested in formalitics. Provided they were satisfied that the will represented the intent of the testator, they were prepared to overlook such defects as the absence of signature or witnesses. For this reason it was not even insisted that the will be in writing. Nuncupative wills (orally made in the presence of witnesses) are often found. ${ }^{51}$ Equally common are depositions by friends as to the "mind" of the testator: the court, if convinced by the witnesses, thereupon ordered a distribution accordingly. courts even allowed a written will to be varied by oral evidence. ${ }^{53}$

Such practices as to lack of formalities seem less strange when it is remembered that even in England the Statute of Frauds was not enacted till 1677.54 Besides, with respect to English wills of the time, it has been pointed out that a nuncupative will may be impossible to distinguish from a written will. ${ }^{55}$ English wills at this time were very often written on the deathbed. As Swinburn says, "it is received for an opinion amongst the ruder and more ignorant people, that if a man should chance

44. 1 Esser Prob. Records 146, 2 id. at $36,51$.

45. 1 id. at 137 .

46. 1 id. at $20,77,133,307,310,319$, etc.; 2 id. at $34,36,71,79,100$, ctc.

47. See, however, the case of the will of Bozoone Allen (1052) where a seal was accidentally torn off and the will promptly taken before the magistrates for inspection. 1 Suffolk Prob. Records 287-289.

48. "All persons which are of the age of 21 yeares, and of right understanding and meamories, whether excommunicate or condemned shall have full power and litsertic t.) make there wills and testaments, and other lawill alienations of theire lands and estates." Body of Liberties, 1641, in Mass. Col. Laws 1660-1672 (18S9) 35, c. 11. Sce also Laws aNd Liberties of Miass. (1929) 1; Mass. Col. Laws 1660-1672 (1899) 121.

49. 1 Essex ProB. Reconds (1916) 3,12, 24, 40, etc. Women's wills are not frequent, however. See note 86 infra.

50. 2 Essex Prob. ReCORDS (1917) 195.

51. The earliest we know of in Massachusetts Bay was in 1633. 1 Reconns of M.Lss. (1853) 153. See also 2 Reconds of the Assistants (1904) 57; 1 Essex Prod. Recoros (1916) $44,50,388,389,446$.

52. 1 Essex Prob. Reconds (1916) 86-\$7; 2 id. at 159-160; 2 Suffoll: Cousty Records 996.

53. 1 Essex Prob. Reoords (1916) 301-302.

54. 29 CAR. II, c. $3 \$ 5$ (1677).

55. Early Lincoln Wills, II, 10 Lrwoold Recono Soc. Pube.(Foster's cd. 1910) svii. 
to be so wise, as to make his will in his good health, when he is strong and of good memory, having time and leisure, and might aske counsell (if any doubt were) of the learned; that then surely he should not live long after." we know that a testator sometimes died before he was able to sign the document. ${ }^{57}$ It must also be recalled that even by the seventeenth century the medirval notion had not quite disappeared that a writing was not dispositive but merely evidentiary. ${ }^{58}$ Again, it must be emphasized that the courts were anxious to carry out the deceased's wishes as far as possible, so as to avoid the more mechanical distribution by the intestacy law. The evidence or testimony offered might not always be convincing, ${ }^{\text {"in }}$ or it might be disputed. ${ }^{60}$ But if it were believed, the defects in the instrument would generally be supplied; and the court would orcler a distribution "as neere as may bee according to the minde of the deceased."

Intestacy also resulted, as indicated above, when a testator neglected to name executors in a will. This requirement for the validity of a will dated back to a time when the naming of the executor was the heart and core of a will, and was as important as the will itself. ${ }^{\text {"1 }}$ By 1600, however, it had become merely a technicality even in England; that is, an administrator was appointed by the ordinary, but the "imperfect" will was annexed to the letters of administration. ${ }^{62}$ So, too, in Massachusetts :

56. Swindurn, Brief Treatise of Testaments (1611) 28.

57. Thus, a will in the Lincoln Consistory Court, dated 1635, which is nuncupative in form, has a note to this effect. See Early Lincoln W'ills, II, supra note 55, at xvii. See also Brown v. Sackville, Dyer 72 a, pl. 2, 73 E. R. 152 (K. B. 1552), where a dying: man's will was taken down in the form of notes; later the will was drawn up, but the man died before he saw it. It was held to be valid.

For an oral revocation of a written and spoken will, see Early Lincoln Wills, II, supra note 55, at 14.

58. See $i d$. at xvii, and cf. Haskins, Chartcr Witness Lists (1938) 13 SyeculuM 319,322, n. 3.

59. 2 Essex Prob. Records (1917) 174-175. Compare the case of John Endecott's will in 1659 , to which there had been no witnesses. It was voted "by the whole court together that they doe not approove of this instrument to be the last will \& testament of the late Jno. Endecott Esqr. Governor." 40 Essex Isstit. Hist. CoLl. (1904) 212. A contemporary (1663) Maine case is interesting. Deceased had made a "deede of gyft" which he had signed and sealed. It was presented as a will by his son, but rejected by the court. 2 LibBy, Province and Court Records of Maine (1931) 383-385.

60. 3 Essex Instit. Hist. Coll. (1861) 190-191.

61. Cf. Fleta (Selden's ed. 1647) bk. II., c. 57, § 13; Britron (Nichals' ed. 1901) c. $29, \S 35$. Swinburn repeats the notion explicitly, although he elsewhere qualifies its operation. The naming of an executor, he says, "is said to be the foundation, the substance, the head, and is indeed the true formall cause of the Testament." Swinuurs, op. cit. supra note 56 , at 8 . The early executor is not unlike the institulio heredis in Roman law; "testamenta vim ex institutione heredum accipiunt et ob id veluti caput atclic fundamentum intellegitur totius testamenti heredis institutio." Institutes of Justinian: II. 20.34 .

62. SWINBURN, op. cit. supra note 56, at 340 . 
although the court recognized the will as defective for want of executors, an administrator was appointed and the estate ordered to be distributed according to the will. ${ }^{63}$ Such a result is even less surprising in riew of the court's attitude toward formalities of execution and the general desire to gire effect to the deceased's intent.

No cases have been found of wills which disposed of only part of the estate, with a resulting partial intestacy. The reasons are perhaps not hard to find. In the first place a will was generally written in a testator's last sickness when he had not long to live. ${ }^{\text {.t }}$ Hence the question was not likely often to arise. The fact that realty was in effect treated as personalty would further exclude the doctrine as to after-acquired property. In the second place, the legatees were often left their shares in portions - one half, one third, or the like; this was particularly so in the case of near relatives. In addition, residual clauses, the catch-all for oversights, were very common.

For all the lack of insistence on form in early probate procedure, and the effort to discover the deceased's intent, intestacy was common. It has been pointed out that wills were generally made on the death-bed or in the last sickness, despite the scriptural injunction to "Set thine house in order; for thou shalt die, and not live." The wills, for example, very frequently begin with a statement that the testator is "weak in body but of perfect understanding and memory"; ${ }^{65}$ and, again, a comparison of the dates of wills with the dates of probate shows little time intervening. ${ }^{66}$ It was in cases where a man died without leaving a will, or where the formalities of his will were considered too defective, that the Massachusetts intestacy law operated.

The basic rules for distribution were the sections of the Body of Liberties of 1641 , and the enactment of 1649 already quoted. ${ }^{67}$ These remained substantially unchanged during the period under consideration, although the interpretation was very often fitted to the particular case in hand. Contrary to the common law of England, where the real estate went directly to the heir and did not come within the jurisdiction of the courts of probate, land and personal property in Massachusetts Bay were valued together and were administered in one indiscriminate mass. The surviving inventories of decedents' estates, of which there are a very large number, show this practice in operation. It is within this frame-

63. 1 Essex Prob. Reconos (1916) 200, 220, 314; 3 id, at 198; 1 sufillol: Prob. Records 407, 409.

64. A comparison of the dates of wills and of the inventuries presented aiter death brings this out clearly.

65. For example 1 Essex Prob. Reconds (1916) 25, 28, 43, 67, 73, 76, cte.

66. The same is true at an earlier day in England, in spite of the surposed hurrew of intestacy in the Middle Ages. See Gross, The Madiceal Laa of Intestury (1904) Is HARV. L. REv. 120.

67. Mass. Col. Laws 1660-1672 (1889) 51, 201. See supra at 1282. 
work that the custom of partible inheritance among descendants operated with respect to fee simple land. ${ }^{68}$ It remains to consider its application in further detail.

The first claim against the estate, before the children could participate, was the widow's share. Following the common law rule of dower, the widow's basic portion from almost the beginning seems to have been a one-third interest in her husband's lands for life. By enactment in 1647, a widow received a one-third interest for life in the houses, lands, tenements and hereditaments of which her husband had been seised during coverture. ${ }^{69}$ This included also one-third of the personalty absolutely, but the addition was dropped in $1649 .{ }^{70} \mathrm{~A}$ widow was entitled to take in three cases only: (a) when she had lived with her husband, (b) when she had not lived with him but was absent by his consent, through his "meer default," or "inevitable providence", (c) when they had been divorced and she was the innocent party. ${ }^{71}$ This interest was free from

68. There is some confusion in the records and the early authorities as to whether the rules of partible inheritance extended to a fee tail in Massachusetts, or whether primogeniture prevailed. In Baker v. Mattocks, Quincy 69 (Mass. 1763), the couttt construed the Province statute of 1692 as not extending to estates tail, thus holding that the common law rule of primogeniture prevailed. Cf. The Charter and General Laws of the Colony and Province of Massachusetrs Bay (1814) 230-232. Earlier in the century, however, the court reached an opposite result in two cases: see Monks, of. cit. supra note 3 , at $100-101$. Yet in 1723 the council passed a declaratory resolution that the Statute of 1692 did not apply to estates tail: 5 JourNals of THE House of REpREsentatives of Massachusetrs (1924) 279. The real difficulty is that the Statute of 1692 refers explicitly to fee simple estates. The earlier enactments, in 1641 and 1660 , in providing for descent to all children, make no distinction between fee simple and fee tail estates: Mass. CoL. Laws 1660-1672 (1889) 51, cc. 81, 82; 201. Morrus, op. cit. sitpra note 3 , at 102 , has concluded that partible descent existed as to fee tail estates diring the seventeenth century. It is noteworthy that Plymouth enacted in 1685 that "all Lands heretofore Intailed, and that shall be Intailed hereafter, shall descend and enure as by the Law of England the same ought to do." Brigham, Compact and Cunaktek (1836) 299. This parallel might tend to weigh in favor of the view that in the Bay Colony rules of partible inheritance applied to estates in fee tail, since no contrary enactment exists. But the use of the words "fee simple" in the 1692 statute equally supports an opposite view. The question must remain an open one until more evidence than the enactments comes to light.

69. Laws aNd Liberties of Mass. (1929) 17-18.

70. 2 Records of Mass. (1853) 281, 3 id. at 169-170: amendment to the 1647 law to strike out the clause "a third part of her husbands money, goods, \& chattels, reall and personall." The effectiveness of the amendment is perhaps open to question. Thus, 3 RECORDS OF THE Assistants (1928) 91: "by A third part for the wife to be ment a third part of the whole." This declaration was made in 1656 by Governor Endecott. Sce id. at 208, where a committee was appointed by the court "to lay out the peticonr hir Just Thirds as the law directs." (Italics mine). Curiously enough, the excision in 1649 was voted at the same session (May 2) at which Endecott was elected Governor. 2 Reconus of MASS. (1853) 265.

71. Laws and Liberties of Mass. (1929) 17 
the claims of creditors. ${ }^{72}$ Prior to 1647 there had been no provision for dower, as the preamble to the act shows. ${ }^{73}$ But a section in the Body of Liberties of 1641 had provided she should not be destitute:

If any man at his death shall not leave his wife a competent portion of his estaite, upon just complaint made to the Generall Court she shall be relieved. ${ }^{74}$

Evidently this enactment continued in force even after the enactment of the law concerning dower. The courts interpreted the provision as meaning the widow was to have, in addition to dower, whatever more was necessary for her support. ${ }^{7 \sigma}$ The practice was given the added force of enactment in the law of 1649 , whereby the county court was given power to assign to the widow "such a part of his personall estate as they shall conceive iust and equall." 70 In fact, there are a few indications that the widow was thought in some sense her husband's heir. ${ }^{77}$ In the famous Patten litigation, for example, the courts maintained the right to give intestate land to the widow in preference to the collateral heir of her husband. ${ }^{78}$ Normally this added share of the widow's would not be exempt from creditor's claims, ${ }^{79}$ but there are one or two instances where the widow's entire share - dower and added portion - was first set aside and the creditors thereafter paid proportionately. ${ }^{80}$

When the widow received a disproportionate share of the estate, it was very frequently because there were young children to be reared, ${ }^{81}$ or because the children had left home and did not need their portions. ${ }^{82}$

72. ". . . freely discharged of and from all titles, debts, rents, charges, judgements, executions and other incumbrances whatsoever had, made, or suffered by her said Husband during the said marriage between them." Id. at 17 .

73. "Forasmuch as no provision hath yet been made fur any certein maintainance for Wives after the death of their Husbands . . . Id. at 17. The earlier pruticien of 1641 was of a very general character and was clearly "uncertain." See note 74 infra.

74. M.Ass. CoL. Laws 1660-1672 (1889) 51, c. 79.

75. 1 Essex Prob. Records (1916) 50, 67, 91, 104.

76. 2 Recoros of Mass. (1853) 281; 3 id. at 170; Mass. Cul. L.aws lofu-1672 (1889) 201, c. 3.

77. As when the widow takes the entire estate with apparent disregard of the rights of lineal or collateral heirs. 1 ESsEX PROB. Reconns (1916) 287-285; 2 id. at $130,165$. The 1649 law speaks of "children or other heires" but is completely indefinite as to who are heirs. Mass. CoL. Laws 1660-1672 (1889) 201, c. 3.

78. Patten v. Dyer, 1 Records of tHe Assist.1nts (1901) 4.

79. See 1 Essex Prob. Reconds (1916) 366.

80. S. F. 245. Also, 2 Essex Prob. Reconns (1917) 162; of. 1 id. at 243. The iact that the courts were occasionally petitioned for permission to sell land suggests the added portion may have included some sort of homestead exemption. See S. F. 530, 53t. Soe also 1 ReCORDS OF MASS. (1853) 278, 292; 2 id. at 254.

81. 1 Essex Prob. Reconds (1916) 50, 67, 91-92, 343-364, 365.

82. 1 id. at $287-288,2 i d$. at 280 . This again emphasizes the suggestiun, nute 77 supra, that the widow was sometimes thought of as her husband's heir. 
Frequently she was required to give security to administer the estate in case of remarriage, ${ }^{83}$ or for the portions of the children to be given them at age or marriage. ${ }^{84}$ Thus the children's interests would be amply safeguarded. In short, the settlement of the estate with regard to the widow's share shows concern for the maintenance of the home and for fair adjustments in the individual case. The share would apparently vary according to need, and might be anywhere from the basic one-third up to the whole estate. ${ }^{85}$

After the widow had received her allotted share, ${ }^{86}$ and the debts of the estate had been paid, the remainder went to the children. If no widow survived, the children took all. ${ }^{87}$ From the start, the courts provided a share for all the children. ${ }^{88}$ The first enactment on the matter came in 1641, in the sections of the Body of Liberties already quoted. ${ }^{80}$ By this law, when parents die intestate, the eldest son is to have a double portion; when there are no heirs male (i.e., sons) the datghters are to take as coparceners. Equality of shares is fairly to be understood from this enactment, both in the calculation implicit in the double portion and in the provision as to coparceny. This manner of division, already operating by the time the law was enacted, ${ }^{00}$ remained the basis of the intestate scheme of distribution throughout the colonial period. An act of 1649 impliedly lodged power in the county court to vary the portions, by authorizing it to "devide and assigne to the children, or other heires, their severall partes and portion out of the said estate." 01 The probate

83. Sec, e.g., S. F. 530. See also 4 Essex Instit. Hist. Coll. (1862) 64.

84. See, e.g., 1 ESSEX Prob. Records (1916) 188; 2 id. at 110, 146. The new husband might also be required to furnish the security. $2 \mathrm{id}$. at $258,271$.

85. The following are roughly calculated as examples of the varying share of witlows in intestates' estates: (a) one-third, 1 id. at 294-295, 324, 377, 434; (b) onc-half, $1 \mathrm{id}$. at $327,353,2 \mathrm{id}$. at 138,188 ; (c) two-thirds, $1 \mathrm{id}$. at 173 , bis. (d) whole, $1 \mathrm{id}$. at $287-288,357,363$; (e) whole for life or until remarriage, 1 id. at $314-315,2$ id at 129. 130.

86. The question of the rights of a surviving busband does not seem to have conce up in the seventeenth century. No cases in which a husband took on a wife's dying intestate have been found in the material examined. Curtesy was not mentioned in any of the enactments of the Bay Colony. Indeed, it seems to have been unusual for a husband to survive his wife. Almost all the estates of women probated in Essex were those of widows. It is unlikely, also, that many women had property of their own unless they had survived their husbands. At any rate, it is worthy of note that only $8 \%$ of all the estates administered in Essex in the ten years from 1675-1685 were those of women. For an eighteenth century case involving a husband's interest in his deceased wife's rcalty, see MorRIs, op. cit. supra note 3 , at 164, n. 7.

87. See, e.g., 2 Essex Prob. Records (1917) 146-147.

88. 2 RECORDS OF THE Assistants (1904) 51 (in 1634).

89. MAss. CoL. LAws 1660-1672 (1889) 51, cc. 81, 82, supra at 1282.

90. See 2 Records of the Assistants (1904) 97.

91. 2 Records of Mass. (1853) 281, 3 id. at 170; Mass. Col. Laws 1660-1672 (1889) 201 , c. 3. 
records, at least, show variations in cases of hardship, or where some of the portion had been already received. ${ }^{92}$

The early provision as to the coparceny of the daughters has sometimes been interpreted as meaning that the daughters were to take only in the absence of the heirs male, i.e., of sons. Much evidence in the records shows clearly that daughters and sons took together, both before and after $1641,{ }^{93}$ and that the section merely provided how the daughters were to hold the property in the absence of sons. ${ }^{9 t}$ The ambiguity was removed by the language of the 1649 act which speaks of "children or other heires." 95

The cases arising during the succeeding years indicate that the law was administered in conformity with the provisions of the early act. Realty was first assimilated to personalty, and the total estate was then divided among the children equally, ${ }^{96}$ with a double portion to the eldest son. ${ }^{97}$ It made no difference that the intestate might be the mother and not the father, ${ }^{98}$ for the 1641 law had spoken of parots dying intestate. ${ }^{39}$ The portions were often determined with reference to the needs of the child, or of the family as a whole. Thus, the taking might be postponed till age or marriage, ${ }^{100}$ or the widow might be given a greater share in order to rear the children. ${ }^{101}$ Provision might be made for increasing the portions in case the widow remarried. ${ }^{102}$ If the estate were small, the eldest son might not receive the double portion. ${ }^{103}$ In two cases, after making the distribution, the court ordered "the overplus to be given to the eldest daughter, she being a lame child." ${ }^{104}$ The

92. See notes $104,108,109$ infra.

93. 2 Reconds of the Assistants (1904) 97; 1 Essex Prob. Reconas (1916) 11, $62,91,118,173,201,325-326 ; 2$ id. at $92,103,193,271,307-308$, etc.

94. It does not appear from the records whether or not coparceny was always followed. See 1 Essex Prob. Reconds (1916) 371, where there was an equal division listween two daughters, but one took the realty, the other the personalty. Huwever, there may have been an agreement between them to this effect.

95. 2 Reconds of MIASS. (1853) 281, 3 id. at 170; MAss. Col. L.avs 1660-1672 (1889) 201, c. 3.

96. See, e.g., 1 Suffolk County Records, 119, 223, 225; 2 id, at 996, 1015, 1017, $1067,1167$.

97. See, e.g., 1 Essex Prob. Records (1916) 44, 62, 91, 201, 325, 353, 377, 384. See also references cited supra note 96, and 1 .1Tiddlesex Conmty Papers, supra note 19, at 481, no. 1178. Cf. 2 Libey, Pronixce axn Colrt Recinds uf Miane (1931) 335, 429.

98. Examples of the partible rule applied to a mother's estate may be found in 1 Essex Prob. Reconos (1916) 57-58, 62, 201, 371; 2 id. at 94, 96.

99. Mass. Col. Laws 1660-1672 (1889) 51, cc. 81, 82.

100. See, e.g., 1 Essex Prob. Reconds (1916) 395, 455; Pynchon's Notc-Bool, supra note 19 , at 68 .

101. See note 81 supra.

102. 1 Essex Prob. Records (1916) 423.

103. 3 id. at 186 .

104. 2 id. at $171 ; 2$ Reconos of The Assistanis (1904) 91. 
doctrine of advancements was well recognized in the colony. Although not effectively a part of English law until $1670,{ }^{105}$ it was recognized by Littleton ${ }^{106}$ and is spoken of by Coke as being characteristic of distributions in the City of London. ${ }^{107}$ As early as 1638/39 it was decided that children who had received their portions were excluded from the distribution. ${ }^{108}$ Other instances have been noted during the period. ${ }^{109}$

Specific agreements among those entitled under the intestacy law might further vary the portions, ${ }^{110}$ or might confirm them in cases where the law might otherwise not have been followed.111 Such agreements indicate that the provisions of the intestacy law were treated as directory only, and that the courts were primarily interested in fairness and in an adjustment satisfactory to the parties.

When no children survived the parent, it is not entirely clear how an intestate's estate was divided. The third chapter of the intestacy law speaks of the shares due "children or other heires." 112 What "heires" meant, who were heirs, the Massachusetts enactments do not say. As already indicated, it is conceivable that a wife was thought in some sense her husband's heir. ${ }^{113}$ In one case the mother and father became the heirs of an intestate who seems to have died without children ; ${ }^{\mathbf{1 1 4}}$ in another, where the parents were dead, the brothers and sisters took equally. ${ }^{115}$ In the famous Patten litigation, already referred to, ${ }^{110}$ the deceased's nephew - son of a younger brother - was preferred to the deceased's older brothers. ${ }^{117}$ The judgment was affirmed by the Court of Assistants, ${ }^{118}$ but was modified later by the General Court in such a way as to divide the part not assigned to the widow between the two claimants, nephew and uncle, in equal shares. ${ }^{110}$ Such evidence

105. $22 \& 23$ CAR. II, c. $10, \S 5$.

106. Co. Lis. ${ }^{*} 179 \mathrm{~b}$.

107. Id. at $* 176 \mathrm{~b}$. For York, where similar rules prevailed, see Swinnurs, op, cit. supra note 56, at $117 \mathrm{ff}$. See also Exeter, 2 BAteson, Borougu Custous (1906) 133.

108. 1 Essex Prob. Records (1916) 11.

109. 2 id. at 142; 2 Suffolk County Records 992.

110. 2 Essex Prob. Reconds (1917) 142-143, 160, 162, 176, $398 ; 3$ id. at 373.

111. 2 id. at $96 ; 3$ id. at 199.

112. Mass. Col. Laws 1660-1672 (1889) 201, c. 3.

113. See note 77 supra.

114. 2 Essex Prob. Records (1917) 132.

115. $2 \mathrm{id}$. at 132. Here, however, the man's estate consisted of the portion left him by his father. But see 2 id. at 193.

116. See note 78 supra. See generally Chafee, Professor Bcale's Ancestor, in HAlvard LEgat Essays (1934) 39.

117. Patten v. Winsley, 1 Suffolk County Records 377 (1673).

118. 1 Records of the Assistants (1901) 4.

119. 5 Records of MAss. (1854) 23-24. Cf. the agreement preserved in S. F. 1403/5 in execution of this order. 
seems to confirm Professor Chafee's statement that the principle of equality among the children extended to others who took in their stead. "If primogeniture was rejected for children, it would also be rejected for collateral heirs."120

Thus from the earliest days of the colony, we can see in operation a law of intestacy of which the most marked characteristic was partible descent of realty and personalty among the children. ${ }^{121}$ This scheme of intestate succession was a clear departure from the common law of England, where the realty went to the eldest son. It was also unquestionably a violation of the charter of 1629 , which gave the colony power to make laws "not contrarie or repugnant to the Lawes of this our Realme of England"; ${ }^{122}$ and for this reason the system was subjected to censure from the Government in England. ${ }^{123}$ In the revision of the Province laws in 1692, the General Court felt obliged to insert in the chapter on wills and intestacy a long preamble justifying divisible descent and the departure from English law. ${ }^{124}$ In the eighteenth century a controversy arose over the legality of the Massachusetts law of intestate distribution. This was the case of Plillips 2 . Sazage, which began in the Suffolk County Court in 1733 and was ultimately appealed to the Privy Council in $1738 / 39 .^{125}$ Primarily it put in issue the constitutionality of the section of the Act of 1692 dealing with intestacy. ${ }^{126}$ Although the latter was in general declaratory of prior enact-

120. Chafee, supra note 116 , at 55 .

121. Professor Andrews is mistaken in thinking the intestacy law did not treome a law in Massachusetts until 1692. Andrews, The Influcnec of Colonial Conditions as Illustrated in the Connecticut Intestacy Lai', in 1 SELET Essays I: A:tolo-Aurenca:: LEGAL HisTORY (1907) 431, 437.

122. 3 Thorpe, Federal and State Constitutions (1909) 1853.

123. For example, the objections by the Attorney General in 1667, replied to by the General Court, in 5 ReConds of Mass. (1854) 199. See comment in 1 Hutear:ison, History of the Colony and Prontece of Mlassachusetts Bay (Miayo's ed. 1936) 377.

In an earlier day, when objection was made by the colonists in 1646 to the arbitrary power of the magistrates, Winthrop and others felt called unon, in justifying the correspondence between colonial law and common law, to claim the highly dubious authority of English law for the eldest son's double portion. MLorris, MLassachuselfs and the Common Law (1926) 31 AsIER. Hist. Rev. 443, 447.

124. "Whereas estates in these plantations do consist chiefly of lands, which have been subdued and brought to improvement by the industry and labour of the proprietors, with the assistance of their children, the younger children generally having boen longest and most serviceable unto their parents in that behalf, who have not personal estate to give out unto them in portions, or otherwise to recompense their labours . . .." The Charter and General Laws of the Colony ano Provicice of Alassachusetts BAY (1S14) 230.

125. The report of the Privy Council is in 3 Acts of the Prary Covicis, Col. Ser (1910) 433. The decree is in no official report, but may be found in 13 Mass. Hist. Soc. Proc. (1S73-1875) 101-103.

126. The Charter and Generat Laws of the Colony aido Pronize of MrassaCHUSETTS BAY (1814) 230. 
ments and of the law long administered in the courts, the earlier acts had never been passed on in England. ${ }^{127}$ The Connecticut intestacy law, which apparently was based on that of Massachusetts Bay, had been declared illegal only a few years before by the Privy Council in Winthrop v. Lechmere (1728). ${ }^{128}$ Nonetheless in Phillips $v$. Savage the distribution made in accordance with the 1692 act was affirmed. In recommending this result to the King, the report emphasized the approval of the Massachusetts laws in 1695 and 1731 by the Lords Justices in Council. ${ }^{120}$ In also emphasizing that the intestacy law was of long standing, the Committee implied that it had had its approval by use and custom. ${ }^{130}$ No doubt they were impressed by the respondent's brief, which stressed the reasonableness of the law with reference to the social and economic conditions of the colony. ${ }^{131}$ In this way the Massachusetts intestacy law was approved by the royal authority.

The law of partible descent seems on the whole to have achieved fair and desirable results. The absence of formalities allowed the courts to give effect to the deceased's intent, insofar as that intent could be ascertained, and the courts seem to have administered estates wisely and well. All members of the family were in some way provided for, and the flexibility of the law permitted adjustments to the needs of the individual case. Thus, those children who had received their portions or who had left home were excluded from the distribution. If the children were young, the importance of preserving the fanily unit was recognized by giving the widow the bulk of the estate. Again, in cases where the need of the widow or of a particular child was very great, an additional share was allotted.

That the law met with approval we cannot doubt. Not only was it consistently reaffirmed and corroborated by enactment and court practice, but many wills followed exactly the provisions of the intestacy law as to equality of distribution and the double portion to the eldest son. ${ }^{132}$ This general acceptance is proof of the law's close adaptation to the colonists' needs. But when this is admitted, we are led to inquire how partible descent came to be adopted in the first place. To this question,

127. Except for the objections to the provisions against forfeitures by the Attoruiey General in 1667, note 123 supra.

128. 3 Acts of tee Privy Council, Col. SER. (1910) 139-151. The decree is printed in 5 MAss. Hist. Soc. Coll. 6th ser. (1892) 496-509. Further papers connected with the case may be found in 5 Cons. Hist. Soc. Coll. (1896) $418 f f$.

129. 3 Acts of the Privy Council, Col. Ser. (1910) 435, 436. Cf. 5 Minss. Hist, Soc. CoLt. (1862) 78-80.

130. 3 Acts of the Privy Council, Col. Ser. (1910) 436.

131. 5 Mass. Hist. Soc. Coll. (1862) 78-80.

132. See 1 Essex Prob. Records (1916) 81, 124, 167, 238, 368, 399. Sce also, S. F. 120, 333/10; 1 Suffolk Probate Records 287-289; 4 Essex INstit. Hist, CoLl. (1862) $68 ; 40$ id. at 214 . 
in the absence of any direct evidence, no final answer can be given. Analysis of the various forces at work will, however, clarify the possible solutions of the problem.

\section{II.}

Several theories have been advanced to explain the existence of partible inheritance in Massachusetts and other New England colonies. Among legal writers, it has often been said that the American scheme of partible inheritance is based on the English Statute of Distribution. ${ }^{133}$ but this notion is clearly false as far as New England is concerned. The obvious objections are that the early Massachusetts laws of 1641 and 1649 long antedate this statute in providing for equal distribution, and that the statute concerned personalty and not land. On a more serious level, several historians have urged that partible inheritance is the necessary consequence of the provisions in colonial charters by which the land was granted to be held as of the royal manor of East Greenwich, Kent, in England, in which inheritances were supposedly partible by the custom of gavelkind. ${ }^{134}$ Others have found the source in Mosaic law ${ }^{135}$ or the economic and social conditions in the colonies. ${ }^{13 B}$

The theory which looks back to gavelkind and the charter merits some discussion. ${ }^{137}$ Its proponents have contended that land in Massachusetts was attached to the Kentish manor for the express purpose of maling gavelkind an incident of the tenure. ${ }^{138}$ The chief peculiarity of this system of tenure was that the lands of a decedent, instead of descending to the eldest son, were divided equally among all the sons. Because of a general presumption at common law that gavelkind attached to all

133. 22 \& 23 Car. II, c. 10. See Reppy and Tomphins, Historical and Staturusy

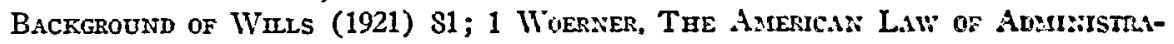
TIONs (3d ed. 1923) $\$ 64$.

134. Iands included in the grant to the Massachusetts Bay Company were to te hell of the king, as of the manor of East Greenwich in the County of Kent, "in iree and common Socage and not in Capite, nor by Knights Service." 3 Tucsre, Feuzr.r ano State Constirutions (1909) 1849. The clause is found in contemporary New England grants: New England Council, 3 id. at 1834; Maine, 3 id. at 1627; Connecticut, 1 $i d$. at 536; Rhode Island, $6 i d$. at 3221.

135. Morris, op. cit. supra note 3, at 111-112; Egleston, The Land Systch of the New England Colonies in 4 JoHxs Hopwns Stumes, supra note 4, at 56 . Of the same opinion was Peter Oliver, Chief Justice of Massachusetts, in 1773. I Lirenany Duars ur EzRA STIIES (1901) 331.

136. Notably Andrews, loc. cit. stpra note 121 ; and Chafce, supra note 116, at 50.

137. For a complete discussion of the "gavelkind theory" see a parer by Hastins, Gavelkind and the Charter of Massachusetts Bay, in the forthcoming volume of Tri:SACTTONS of the Colonial Society of Mfassachusetts.

138. A partial list of these writers may be found in Mosers, of. cit. sufra nute 3, at 106, n. 2. 
lands in Kent, ${ }^{139}$ it was thought to follow that it obtained in East Greenwich and was therefore extended to New England by the seventeenth century charters. The apparent similarity between this mode of descent and that in seventeenth-century Massachusetts led to the easy conclusion that the Massachusetts custom was gavelkind.

Comparison of the incidents of gavelkind with the customs of descent in Massachusetts provides convincing evidence that gavelkind did not exist in the Bay Colony. There are roughly five main characteristics of gavelkind. ${ }^{140}$ (1) On the death of a proprietor, the lands were divided equally among his sons or their representatives. (2) The wife's dower, instead of being one-third as at common law, was one-half of the lands of which her husband had been seised during coverture. (3) The husband's right of curtesy extended to merely one-half, instead of all, his wife's lands. (4) The heirs came of age for purposes of alienation at fifteen. (5) The proprietor's estate was not forfeited for felony, as it was at common law, but the heirs succeeded.

Equal succession was a marked characteristic of the law of descent in Massachusetts Bay; but, as shown above, sons and daughters took equally without discrimination as to sex. ${ }^{141}$ Also, the Massachusetts provision for the double portion to the eldest son again varies the gavelkind formula. In the matter of dower, it is clear that the widow received one-third of the lands for life, and for a time one-third absolutely of the personalty. ${ }^{142}$ Curtesy is not mentioned in the laws or records; ;4a and the age of alienating land was twenty-one, as at common law. ${ }^{144}$ In only one respect, namely, that lands were not forfeited for felony, is there a close resemblance to gavelkind. It seems probable, however, that this is to be traced not to the Kentish custom but to a Puritan mistrust of the feudal system and its incidents. ${ }^{140}$ This interpretation is borne out by the fact that the section of the laws providing that there shall be no forfeitures includes the prohibition with a long list of other feudal privileges. ${ }^{140}$ In short, it is impossible to accept such a contention

139. Browne v. Brokes, 2 Sid. 153, 82 E. R. 1307 (K. B. 1659) : "fuit agréc per" touts que si terre soit alledge d'estre en Kent, serra presume d'estre Gavelkind, si non que le contrary soit prove." Again, Wiseman v. Cotten, 1 Sid. 135, 138, 82 E. R. 1015, 1017 (K. B. 1661): "touts terres in Kent sont suppose destre Gavelkind." See also, Rowinson, GavelKind (1897) 44.

140. For full discussion of these and other incidents, see especially Robinson, GavelKIND (1897) bk. II ; Elton, Tenures of Kent (1867) 39-44; Neilson, Custom and the Common Lawe of Kent (1925) 38 Harv. L. Rev. 482.

141. See note 93 supra.

142. See notes 69,70 supra.

143. See note 86 supra.

144. Mass. Col. Laws $1660-1672$ (1889) 35, c. $11 ; 45$, c. 53.

145. On this distrust of the English land system, see Haskins, The Bcoinnings of the Recording System in Massachusetts (1941) 21 B. U. L. REv. 281, 301-302.

146. Mass. Col. Laws 1660-1672 (1889) 35, c. 10. 
as that of Judge Gray that "the Body of Liberties contained articles upon each of the principle points distinctive of the Kentish tenure of gavelkind."147

A further weakness in the gavelkind theory is that this system of tenure almost certainly never prevailed in East Greenwich itself. The common law presumption that gavelkind attached to all lands in Kent was merely a general rule to aid the courts; it was a rebuttable presumption. ${ }^{148}$ There is ample evidence that many lands in Kent were not gavelkind lands. ${ }^{149}$ Much of it had never been subject to the custom, and more was disgavelled by Act of Parliament in the sixteenth century. ${ }^{150}$ It is true that there is no direct evidence in the Greenwich records or elsewhere that gavelkind did not prevail there. ${ }^{151}$ However, the absence of such evidence is significant ${ }^{152}$ in view of the fact that at the time of the Norman Conquest East Greenwich was held in franlialmoigne or free alms, as appurtenant to the manor of Lewisham, by the Abbot of St. Peters at Ghent in Flanders. ${ }^{103}$ Admittedly gavelkind did not attach to lands held since the Conquest in frankalmoigne. ${ }^{15 t}$ Since the manor remained in the hands of the Abbot in this tenure until the suppression of the alien priories in $1413,{ }^{155}$ by which time the limits of gavellind were well fixed, there can be little question that it was not subject to gavelkind.

Finally, there seems good reason to question how far descent in one set of lands would affect that in another set. Elton, a high authority on gavelkind, states categorically that the tenure of gavelkind could not be created out of the bounds of Kent; "nor can any custom," he says, "whether borough-English, partition in descent, or anything else, be

147. Jackson v. Phillips, 14 Allen 539, 561 (Mass. 1867).

14S. Robinson, Gavelkind (1897) 38-39.

149. Id. bk. I, ch. v.

150. Notably by the statute $31 \mathrm{HEx}$. VIII, c. 3 (1539), and 2 \& 3 Enw. VI, c. 1 (1549).

151. The best general account of the history of Greenwich is in 1 Hasted, Histows of KeNr (1797) 383. There is nothing on our point. The charters and royal grants of the manor are silent in this respect, as are the court rolls and Domesday Bods. For the charters, from the Anglo-Saxon period on, see 1, 2 Var Lokenex, Canares ex Dectareatxs de L'Abbaye de Satnt Prerre (1868) passim. For the court rolls, sce Barnss, Land Tenutre in English Colonial Charters of the Scientecnth Century in Essixs is Colonial History Presented to Charles Micleiar Antrewis (1931) 4, 33 . See also I Dojiesday Book (1783) 12 b (under "Levesham").

152. See a survey of the customs of the manor in 1695 in Kinsoer, Aar Accov:s of the Legacies, Gifts, Rents . . o of the Parish of St. Alpmeje, Gree:uwici (1816) $183,206$.

153. The pertinent charters and grants may be found in 1 VA: Lonene:, of. cif. stspra note 151, nos. 3S, 124, 159, 170, 215. They are discussed further in Hastins, Gartllind and the Charter of Massachusetts Bay, supra note 137, at n. 54.

154. Robinson, Gavelisind (1897) 73-75, Elton, Tencres of Ke:is (1847) $236 \mathrm{fj}$.

155. By the statute of 1 HEN. V, c. 7 (1413). 
newly imposed upon land by any royal grant." ${ }^{166}$ On its face, therefore, it would not seem possible that gavelkind could be extended to the colonies by royal charter, even supposing that gavelkind existed in East Greenwich.

The explanation of partible inheritance in Massachusetts is not, then, to be sought in a transplantation of gavelkind customs from the manor of East Greenwich. Proponents of this view have been deceived by the superficial resemblance between different rules of partible inheritance. The approach, however, has merit insofar as it brings into consideration the influence of the colonists' English background. We must not forget that a number of the settlers did come from Kent ${ }^{157}$ and that the general gavelkind analogy of partibility might for that reason have suggested itself to them. At the same time, partible descent existed in many places in England outside of Kent, ${ }^{168}$ and there is little in Massachusetts history which leads us to derive its intestacy law necessarily from that of Kent. ${ }^{160}$ This caution is even more cogent in view of the marked differences in the details of the two laws of descent. It is rather to elements in the colonists' background that we must turn in order to obtain further light on their adoption of a scheme of partible inheritance. ${ }^{160}$

It seems fair to say that the scheme of partible inheritance in cases of intestacy, which we find in the colonies of Plymouth and Massachusetts Bay in the seventeenth century, had its origin either in the ideas or experience growing out of the settlers' previous backgrounds, or in the environment in which they found themselves, or in a combination of both. Five possible sources of the practice may be suggested. (1) The Dutch or Roman Law scheme of intestate succession, with which the Plymouth settlers, at least, were acquainted from their sojourn in Leyden. (2) Manorial or borough customs of inheritance in those parts of England from which the colonists came. (3) Practices of intestate distribution of personalty made by the courts of the ordinaries in England. (4) The Mosaic rule of descent laid down in the Old Testament and inter-

156. Elton, Tenures of Kent (1867) 157. He is supported by Robinson, GavelKIND (1897) 55, 61, who is explicit to the effect that gavelkind customs cannot be imposed on land which had never been subject to them. For a consideration of early cascs, see Haskins, Gavelkind and the Charter of Massachusetts Bay, supra note 137, at n. 60 .

157. Cf. Hoar, in Axrer. Antro. 'Soc. Proc. (1883-1885) 369.

158. This is discussed pp. 1302-1304 infra.

159. See, however, the reply by the General Court in 1667 to certain objections by the Attorney General, in 5 Records of Mass. (1854) 199. The assertion may merely be a legal argument which they hoped would stick. It is worth noting here that partible inheritance, whether in or outside Kent, was frequently termed gavelkind in the sis:teenth and seventeenth centuries. Elton, TeNurEs of KENT (1867) 53-54.

160. The notions that Mosaic law or economic conditions in the colony are to be looked to as the origin of the practise are not discussed independently from the main exposition below. Neither has ever been worked out in any detail, so that it seemed advisable to include such references as there are to the theories in the general treatment. 
preted in relation to Puritan social and religious ideals. (5) The exigencies of social and economic life in the new frontier community in which the settlers found themselves.

The Dutch scheme of intestate succession cannot be ignored, but it is difficult to assess its rôle with any certainty. While it could not have influenced the settlers in Massachusetts Bay directly, it might have done so indirectly through Plymouth. More than one of the achievements of Plymouth Colony seem to have been borrowed by its neighbor: ${ }^{101}$ for example, Congregationalism, ${ }^{162}$ the device of codification, ${ }^{103}$ and the elements of the recording system. ${ }^{104}$ The possibility that Massachusetts Bay drew upon Plymouth experience is therefore one which throughout the discussion must not be overlooked. Moreover, it will be remembered that the characteristic feature of colonial partible inheritance-equal succession among all children, and a double portion to the eldest son - made its first appearance in Plymouth. ${ }^{105}$ Many of the Pilgrims had lived in Holland in close contact with the Dutch. ${ }^{16 s}$ Mrany had died there. Before 1620 , there were 288 known members of the Pilgrim group in Leyden, of whom 33 became citizens of Leyden; ${ }^{167}$ and between 1620 and 1633, 81 members of Plymouth Colony migrated from Leyden. ${ }^{168}$ There would therefore have been opportunity to learn of the Dutch system of intestate succession.

Although there was great confusion in the Dutch law of intestacy in the sixteenth century, ${ }^{169}$ and it varied greatly from place to place, ${ }^{170}$

161. Morison, The Pilgrim Fathers (1937) N. H. MLArrlower Soc. Proc. 5, dissents from this proposition, except possibly for Congregationalism. But see notes 163, 164 infra.

162. Id. at 5 .

163. Goebel, King's Law and Local Custom in Scintcenth Century Ncro Englond (1931) 31 CoI. L. Rev. 416, 418-419, n. 7.

164. Haskins, The Beginnings of the Recording System in .Massachusetts (1941) 21 B. U. L. REv. 281,285 n. 19. Such inter-colony borrowing was by no means exceptional. Thus, Connecticut and Pennsylvania seem to have borrowed their intestacy law from Massachusetts Bay, and Delaware in turn from Pennsylvania. As Professor Afcllwain has shown, it can be seen in constitutional doctrine as well as in private law. Cf. MclLwatn, Constitutionalisa and the Changing Worlo (1939) 237.

165. See note 8 supra.

166. See generally Dexter, The England and Holdand of the Puaranis (1905). For real estate transactions, see $i d$. at 601-641; and if. Ploon, The Promns Fatmens (1932) $60,102$.

167. DEXTER, op. cit. supra note 166 , at $648-649$.

168. Id. at 650-652.

169. Excellent brief treatments of the Dutch intestacy law at this time may be found in LeE, AN Introduction to Ronis-Dutch LaW (1915) 327 ff.; 1 VA:? LeEuwe:; Comiztentaries on the Roaran-Dutch Law (Decker's ed. 1921) bli III, ch. xii.

170. Generally speaking there were two laws of intestacy, the Aasdoms-recht in North Holland, and the Schependoms-recht in South Holland. The districts are separated by the river IJssel. An attempt was made in 1581 to establish a common law 
we know with considerable certainty the features of the law obtaining in the two Pilgrim havens, Amsterdam and Leyden, in the early seventeenth century. The Political Ordinance of 1599, accepted by these two towns along with others, provided for: (1) equal division among children, male and female alike; (2) failing children, equal division between the deceased's parents, if both were living; (3) if only one parent survived, then one-half to such parent, one-half to the brothers and sisters who were children of the deceased parent; (4) if neither parent survived, then to the deceased's brothers and sisters on the two several sides. ${ }^{171}$ The obvious resemblance of this scheme to that in use in Massachusetts Bay must not lead us to accept a hasty analogy. While the double portion for the eldest son is conspicuously absent from the Dutch law, the points of resemblance are noteworthy. In Massachusetts the children, male and female, took equally, as under the Dutch Ordinance; and, in cases which have been noted, where the intestate had no children, Massachusetts seems to have followed a rule similar to points (2) and (4) above. ${ }^{172}$ Moreover, it is very likely that under the Ordinance of 1599 a widow might under some circumstances share in the deceased's estate as an heir. ${ }^{173}$ Such — outside of customs like freebench ${ }^{174}$ - had never been the law of England. Yet in some Massachusetts cases the widow seems to have been thought in some sense her husband's heir. ${ }^{170}$ The analogy is not to be pushed too far. But it is worth noting that in another field of law, namely, the adoption of the recording system, Dutch influence may well have been a factor of weight. ${ }^{170}$ It is conceivable, therefore, that we may look for at least one root of partible inheritance in the Dutch law of intestacy obtaining in Amsterdam and Leyden.

Turning to local customs in the districts in England from which the colonists came, we find a perhaps more obvious source of the Massachu-

of intestate succession for the two districts. 1 Groot PLACAer-BoEcK (1658) 335; also, an "interpretation," $1 \mathrm{id}$. at 342 . But the northern towns refused to adhere to the new scheme, which was based largely on the Schependoms-recht. The Political Ordinance of 1599 was based partly on the old Aasdoms-recht, partly on the Schependoms-rccht, and partly on Roman law. 1 id. at 343 .

171. Ibid.

172. 2 EsSex ProB. ReCoRds (1917) 132, cited in notes 114, 115 supra.

173. Lee, The Intestate Succession of Husband and Wife in Roman-Dutch Law (1911) 12 J. Soc. Comp. Leg. 310, 315. The Ordinance of 1599 , of which the provisions are considerably more elaborate than sketched above, provides in Article 14 that in all cases not expressly covered, Roman law is to control: "Eyntlick alle andere Successien daer van hier vooren niet en is ghedisponeert, sullen ghereguleert worden nae de wacrlijcke beschreven Rechten." The pertinent provision in Roman law is D. 38, 11.

174. See note 207 infra.

175. See note 77 supra.

176. Haskins, The Beginnings of the Recording System in Massachusetts (1941) 21 B. U. L. REv. 281, 289-291. 
setts law of partible inheritance. The generalization that in England land invariably descended to the eldest son is an inaccurate one and subject to many qualifications. For example, since the early Middle Ages land had been divided in many manors and towns throughout England among all the children of the deceased. These customs were by no means restricted to Kent. Partible descent, in fact, seems to have been the normal manner of descent of lands in England until the Normans, for military and governmental reasons, began to force on land-owners the system of primogeniture. ${ }^{177}$ In spite of the steady pressure of the royal courts to eliminate exceptions, such customs persisted beyond the Middle Ages in various manors and boroughs among certain classes of tenants below the top brackets of the feudal system. ${ }^{178}$ For our purposes it is significant that such customs of partible descent were wellknown in districts from which the early New England settlers came, and were not confined to Kent.

Instances of partible inheritance are found most extensively in manors in the East of England, particularly in Norfolk and East Anglia. ${ }^{179}$ It is also found in Cambridge, ${ }^{180}$ Dorset, ${ }^{181}$ Gloucestershire, ${ }^{162}$ Leicestershire, ${ }^{183}$ Middlesex, ${ }^{184}$ Nottinghamshire, ${ }^{185}$ and Suffolk, ${ }^{189}$ not to mention other counties. ${ }^{187}$ Such customs were not confined to manors, but existed in many boroughs and towns, ${ }^{185}$ as Dover, ${ }^{189}$ Exeter, ${ }^{100}$ Ipswich, ${ }^{191}$ Torksey, ${ }^{192}$ and Wareham. ${ }^{103}$ Much of the evidence is from the mediæval period; and until more of the later court rolls have been

177. 2 Pollock and Maitland, History of English Law (1895) 260-262. Tacitus noted the existence of partible descent among the Germans in the second century. TAcirus, Germania, XX.

178. Cf. Plucknett, Conctse History of the Common L.aw (3d ed. 1940) 471-472.

179. 2 Pollock and Miaitland, History of Exglisu Law (1895) 268; Douglas, The Social Structure of Mredicval East Auglia in 9 Oxrond Srumes in Sceral axto LEGAL History (Vinagradoff's ed. 1927) 260 ff.; Gray, Exglisn FirLd Syste:rs (1915) 337; Homans, Partible Inheritante of I'illagers' Holdings (1937) 8 Ecor. HISr. REv. 48, 51-55; Hudson, Three Mlanorial Extents of the Thirteenth Ceutury (1901) 14 Norfolm ARChakology 46, n. 1.

1S0. Homans, supra note 179 , at 53, n. 2.

181. Tayior, Gaveimind (1663) 101.

182. Elton, Tenures of Kent (1867) 54,170 , n. m.

183. Homans, supra note 179 , at 55, n. 1 .

184. Elton, Tenures of KeNt (1867) 169.

185. Id. at 54 .

186. Ibid. Homans, stpra note 179 , at 53, n. 2.

187. Elton, Tenures of KeNt (1867) 54, 169-170.

188. Co. Lit. $* 110 \mathrm{~b}$.

189. 2 Bateson, Borough Custons (1906) 133.

190. 2 id. at $132,133$.

191. 2 id. at 132.

192. 2 id. at 133.

193. Taylor, Gavelkind (1663) 101. 
studied, it is not possible to say with certainty how late some of these customs persisted. At the same time, the tenacity of medirval local customs throughout England until well into the modern period is a factor of importance which is frequently overlooked. ${ }^{104}$ There is good evidence that partible inheritance was well known by local custom in the sixteenth and seventeenth centuries; ${ }^{105}$ indeed, it had not entirely disappeared by the time of the First Report of the Commission on Real Property in $1829 .{ }^{106}$

Special incidents might sometimes attach to such customs - as in several places near London, where, if the land were worth under $£ 5$, it descended to the youngest son, but, if over that value, it was partible among all sons. ${ }^{197}$ Yet it should be noticed that these customs were not gavelkind and seldom carried with them any of the characteristics of gavelkind. In most of these cases land merely descended in equal shares among the children. Sometimes "children" meant sons, ${ }^{108}$ sometimes it meant that daughters as well as sons were included to every degree of relationship. ${ }^{190}$ The details might vary indefinitely from place to place, ${ }^{200}$ but the underlying idea of partibility maintained itself with extraordinary tenacity.

In order to make the connection between English and colonial customs plainer, the sources of New England immigration in the seventeenth century must be considered. Bearing in mind the possibility that Massachusetts Bay borrowed the basic idea of its intestacy law from Plymouth, we consider first the districts in England from which the latter colony was settled. The Pilgrims were predominantly from manors and towns in East Anglia, particularly from Norfolk and Essex; nearly one-half of those whose origins are known came from these counties. ${ }^{201}$ York-

194. This is particularly true in the boroughs, where the customs were carly reducer to writing. A very good general treatment of the importance of local custom in mediacval and early modern England may be found in Schechter, Popular Laze and Local Custom in Medieval England (1928) 28 CoL. L. Rev. 269.

195. See Sympson v. Quinley, 1 Vent. 88, 86 E. R. 61 (K. B. 1670), Newton v. Shaito, 1 Sid. 267,82 E. R. 1097 (K. B. 1665). In some places partible descent was changed by royal acts similar to disgaveling statutes. Thus, Oswaldbeck, Notts, 32 Hen. VIII, c. 29 (1540) ; Exeter, Devon, 23 Eliz., c. 12 (1581); Stepney, Hackney and Mile End, 21 JAC. I, c. 6 (1623).

196. First Report Real Property Comm. (1829) 254. The Report indicates that these were "gavelkind," but most of them are outside Kent. Elton, Origins of ENGiLISH History (1882) 193.

197. Id. at 193.

198. Elton, Tenures of Kent (1867) 169.

199. Id. at 169-170; 2 Bateson, Borough Customs (1906) 133 nn. 1, 2; Blounr, Tenures of Land and Customs of Manors (Hazlitt's ed. 1874) 355; Newton v. Shafto, 1 Sid. 267, 82 E. R. 1097 (K. B. 1665).

200. Thus, partibility among daughters only. Brount, op. cit. supra note 199, at 174; Roe d. Raper v. Lonsdale, 12 East 39, 104 E. R. 16 (K. B. 1810).

201. Dexter, The England and Holland of the Purtrans (1905) 650. The classification is necessarily very imperfect, for few records survive. 
shire, Nottinghamshire, Lincoln and Kent were also strongly represented. ${ }^{202}$ It becomes apparent at once, in comparing these sources of origin with the places where partible inheritance prevailed, that many of the Plymouth settlers - countrymen and townsmen - had had opportunities of knowing of these customs. Particularly is this likely when it is remembered that by and large the Pilgrims were men and women of humble origin, for the most part townsmen or of the poorer copyhold class. ${ }^{203}$ Hence, had any of them lived on manors or in boroughs and towns where partible inheritance obtained, they would have had firsthand acquaintance with the custom.

The immigrants to Massachusetts Bay came mostly from the towns and manors of two groups of counties: East Anglia (Norfolk, Suffolland Essex) and the West Country (Cornwall, Somerset, Dorset, Gloucester and Wiltshire). ${ }^{204}$ Again, the predominance of the East county element suggests, as in the case of the Pilgrims, acquaintance with customs of divisible descent in England. Moreover, such customs prevailed in several of the counties of the VWest Country from which the settlers came. Unlike the Pilgrims, the Massachusetts Puritans were of greater wealth and substance than the Plymouth settlers, but their opportunities for acquaintance with such customs were no less considerable.

The hypothesis that local customs in England may have furnished prototypes for partible inheritance in this country is given substance by resemblances between the English and colonial practices. Even in seventeenth century England partible inheritance seems to have been comparatively well-known, and to have extended in some cases to daughters as well as sons. ${ }^{205}$ Moreover, in some parts of England the widow might, as in Massachusetts Bay, take all or part of the deceased husband's property, either in addition to dower ${ }^{208}$ or in place of it.. ${ }^{07}$ The notion of pro-

202. Id. at 650. Dexter estimates that probably scores of those who flcd to Hulland came from Lincolnshire, Nottinghamshire and Yorkshire, but foints out that the Dutch records give only scant information.

203. Cf. Goebel, King's Law and Local Custom in Scrunteonh Contury Ncw England (1931) 31 CoL. L. Rev. 416, 443-444.

204. Banks, English Sources of Emigration to the Now England Colonics in the Sw: enteenth Century (1927) 60 MIass. Hist. Soc. Psoc. 366.

205. See note 199 supra.

206. As at Ipswich, in Suffolk. 2 Bateson, Bokotgr Custons (1906) cis.

207. This was usually freebench. See Co. Lit. $110 \mathrm{~b}-112$ b; 2 BatE:0:ז, Bursuvgr Custoxs (1906) 121-122, 126. Freebench was well known by custom in copylolds, and was really a rule of succession to property. The portion varied considerably from plase to place and might be one-fourth, one-third, or the whole 2 WATwris, Trentise 0:: Copyrolns (1799) 87-90. See also an excellent discussion by Gomme, Iridowhood is Manorial Law (188S) 2 ARChaEological Review 184. In some custumals the wife is explicitly spoken of as her hushand's heir: SHILLibes, Axcient Custuss of tue MLanor of Taunton Deane (1821) 42; of. Martin v. lientworth, Noy 1, 74 E. R 974 
longing the family community is also common to Massachusetts and to certain English borough customs. ${ }^{208}$

Customs by which the eldest son was given preference in certain districts of partible descent in England further hint at the influence of the homeland on the colonies. While only one example of the eldest son's receiving a double portion has been found, ${ }^{200}$ there are many instances of some sort of preference for the eldest from the twelfth century on. ${ }^{210}$ In Bracton's day, in places where the inheritance had been divisible from ancient times, if there was only a single messuage, that remained entirely for the eldest son, though the others received up to its value from the general property. ${ }^{211}$ Where there were several messuages, the eldest among several coheirs had the first choice. ${ }^{212}$ The custom of giving of heirlooms and principals to the eldest son, found in impartible ${ }^{213}$ and partible $e^{214}$ districts alike at least as late as the seventeenth century, are instances of the same preference for the eldest. This tendency can again be found in the occasional preference of the eldest daughter, either among coheiresses, ${ }^{215}$ or by herself on the analogy of primogeniture. ${ }^{\mathbf{2 1 0}}$

In short, certain resemblances between the colonial intestacy law and those of places in England from which the settlers came suggest that Massachusetts Bay may have drawn on English customs - either directly or by way of Plymouth - in working out the beginnings of its law of partible inheritance.

(Q. B. 1596). Again we wish to emphasize how many of the New England colonists were of the copyhold class in England. This fact may in part explain why the widow seems to be treated sometimes as an heir; such practices in Massachusetts Bay may be no more than survivals of the custom of freebench. Freebench should be clearly distinguished from dower, for in some localities the widow took one-hall or the whole by way of dower. See Co. Liт. *33 b, *111 a; Baker v. Berisford, 1 Keble 509, 83 E. R. 1081 (K. B. 1663).

208. 2 Bateson, Borough Custons (1906) cviii.

209. Hudison, Manorial Life (1923) 1 History Tenchers' Miscellany 161, 162.

210. Glanvill, bk. VII, c. 3.

211. Bracton, fol. 76a. Cf. 2 Pollock and Maitland, History of Englisu law (1895) 262; 2 Bateson, Borougr Customs (1906) 133. An entry in British Museum Cot. MS. Tib. B, II, f. 198 (Ely custumal, 1222) seems to show one brother getting three times what the other got. I owe the reference to Mr. G. C. Homans.

212. Bracton, fol. $76 \mathrm{a}$. This custom of first choice in the eldest son was known as ainescia and was well recognized from the twelfth and thirteenth centuries. GLAnvilL, bk. VII, c. 3; Bracton, fols. 76 a, 76 b, 77 a; FletA (Selden's ed. 1647) bk. V, c. 9; Co. Lit. $* 166$ b.

213. Co. LiT. $* 18 \mathrm{~b}$.

214. 2 Bateson, Borough Customs (1906) 143, 144.

215. Co. Lit. *165 a; Elton, Origins of ENGlish History (1882) 203-204.

216. Id. at 204. See also Blount, op. cit. supra note 199, at 219 (Northampton) 265 (Herts.). For the custom in the border counties of the north in the ninetcenth century see Doe d. Hamilton v. Clift, 12 Ad. \& E. 566, 113 E. R. 927 (Q. B. 1840); Doc d. Foster v. Sisson, 12 East 62, 104 E. R. 25 (K. B. 1810). 
A third possible source of the Massachusetts law may be found in the customary distribution of personalty in England. Since realty and personalty were assimilated in the administration of estates in Massachusetts Bay, it has been suggested that the whole was distributed as if it had all been personalty. This notion receives support from the fact that realty and fixtures constituted at first the greater part of the wealth of the early settlers; but it is difficult to analyze the situation adequately, in view of the obscurity of the English law of intestate distribution of chattels before the time of the Statute of Distribution. ${ }^{217}$ Estates were administered for the most part by the ecclesiastical courts according to certain general rules to the effect that the children and the wife of the intestate had some rights in the property. If he left a wife and no children, she took half; if he left a wife and children, they took respectively one-third. The remainder was used by the administrator for the good of the deceased's soul. From an early date the wife and children could get their shares by bringing the writ de rationabile parte bonorum at common law. While York and London had this custom till a late date, ${ }^{\text {,18 }}$ we cannot tell how widely it persisted in the seventeenth century ${ }^{210}$ until more ecclesiastical registers are available for study. In a great many towns, however, where estates were frequently administered before the town officers, ${ }^{220}$ it had become established by the end of the fourteenth or fifteenth century that the chattels of an intestate should go to his wife and children, or, failing these, to his kinsmen. These in turn might be expected to devote a portion of the property to pious works. ${ }^{21}$ Since at first in the colonies there were no fixed proportions into which estates were divided, and the widow might not share in the personalty at all, 202 the influence of the English ecclesiastical or borough schemes of distribution may not have been very great. ${ }^{223}$ Still, the possibility remains;

217. 22 \& 23 CAR. II, c. 10 (1670).

218. In York till 1692; 4 Wr. \& Many, c. 2 (1692); in London till 1724: 11 Gro. I, c. 18 (1724).

219. 3 Holdsworth, History of ExGlise Law (4th ed. 1935) 554 fj.

220. See, eg., London, 2 Bateson, Bonougr Cusroms (1905) 194-195, 196; Oxiord, 2 id. at 195-196; Exeter, 2 id. at 196; Fordwich, 2 id. at 200; Sandwich, 2 id. at 200, n. 6; Dover, $2 \mathrm{id}$. at 201. That this was recognized in the seventeenth century ean be seen from Selden, The Disposition or Administration of Intestates Goods in 3 Orem OMINIA (1726) 1677.

221. Gross, The Medieval Law of Intestacy (1904) 18 Hasp. L. REw. 120, 131.

222. The laws of 1641 and 1649 contemplate merely that the widow shall be adequately provided for. Mass. CoL. Laws 1660-1672 (18\$9) 51, c 79; 201. Several cases show the widow taking only her dower. It will be remembercd that the provision of 1647 giving the widow one-third of the personalty in addition to dower was repealed in 1649. See note 70 supra.

223. Contrary to the general opinion that until 1857 all estates were probated or administered in the ecclesiastical courts, there were in addition to secular administrations in the towns some places in which estates were administered before manorial courts. "By prescription," says Scriven, "a court baron might have jurisdiction as a court peeu- 
and since it seems true that much of the procedural law of succession in this country stems from the practice of the ecclesiastical courts, ${ }^{224}$ some of the substantive law as well may come from this source.

The instinct to imitate or to reproduce the familiar is seldom a complete explanation of social phenomena, and it is not enough merely to emphasize laws and customs in England and Europe with which the colonists were familiar. It must be remembered that the men who settled in Plymouth and Massachusetts Bay had been deeply affected by Calvinism and the contemporary renaissance of biblicism and the exaltation of the Mosaic Law. ${ }^{225}$ Their intellectual background was dominated by religious idealism. To the majority, if not all of them, the word of God was law, and the source of this law was found in the literal Scriptural word. With the teachings of Calvin the New England Puritans were thoroughly familiar, both through their ministers and through the flood of dissentient pamphlets current in England. Calvin had taught that the kingdom of God could be reproduced on earth only by closely following the Hebrew models. ${ }^{226}$ Encouraged by the practical success of Calvin in Geneva in framing laws and a form of government on the basis of Old Testament law, the Puritans in this country attempted to give his theories concrete application. Cotton himself asserted that "the more any Law smells of man, the more unprofitable" it is. ${ }^{227}$ The dominant position of the clergy in New England helped achieve these ends. Thomas Lechford, writing in 1642, pointed out that not only did the ministers advise in making the laws, but they were frequently present in court. ${ }^{228}$ The Plymouth and Massachusetts criminal codes bear the strong impress of their ideas, for many sections are clearly modeled on rules laid down in Exodus, Leviticus and Deuteronomy. ${ }^{20}$

liar, to. grant probate and administration and to take cognizance of testamentary causes." Scriven, Treatise on the Law of Copyholos (7th ed. 1896) 423. Upwards of filty such manors having this jurisdiction in the sixteenth, seventeenth, and eighteenth centuries are listed in Hone, The Manor and Manorial Records (2d ed. 1912) 302-304. Cf. Nicholson v. Shirman, 1 Sid. 45, 46, 82 E. R. 960 (K. B. 1661) : "Testamentary causes . . . fueront prove devant Seigneurs del Mannors . . . come ore sont in ascun lieus." But of the details of such administrations we know practically nothing.

224. In general, see the forthcoming edition of Woerner, Administrations, by Mr. T. E. Atkinson. The seventeenth century was well on its way before the writs of prohibition hampering the jurisdiction of the ecclesiastical courts began to issue. Thus, Slawney's Case, Hob. 83, 80 E. R. 233 (K. B. 1616), Frotherbie's Case, Cro. Car. 62, 79 E. R. 657 (K. B. 1627), Lavanne's Case, Cro. Car. 201, 79 E. R. 777 (K. B. 1631).

225. This background is sketched briefly but admirably by Goebel, King's Lawe and Local Custom in Seventeenth Century Neze England (1931) 31 CoL. L. Rev. 416, 423. 432. See also Morris, op. cit. supra note 3, at 21-41.

226. Calvin, Institutes, bk. I, cc. 7, 8; bk. IV, cc. 8-10.

227. Quoted by Morris, op. cit. supra note 3, at 35 .

228. Lechford, Plaine Dealing or News from New England (1867) 62.

229. See, for example, the Body of Liberties, Mass. CoL. Laws 1660-1672 (1889) 55 , c. 94. 
With the general influence of the Bible on colonial law we are not here concerned. ${ }^{230}$ There is good reason to believe that, insofar as partible inheritance is concerned, the Massachusetts law may have been based on Mosaic law. John Cotton, as a member of a committee appuinted in 1636 to "make a draught of laws agreeable to the word of God","31 presented a proposed code of laws entitled "Moses his Judicialls"."232 Most of the provisions were based on texts of the Pentateuch. Amung them were two dealing with inheritance. So close are they in wording to the two provisions in the Body of Liberties of 1641, that it is hard to believe that the latter were not copied from Cotton's draft.

$\mathrm{V}$. Inheritances are to descend naturally to the next of kinne. according to the law of nature delivered by God. Numb. 27, 7, $10,11$.

VI. If a man have more sonnes than one, then a double portion to be assigned and bequeathed to the eldest sonne, according to the law of God, unlesse his owne demerit doe deprive him of his birthright. The like for personall estates. Deut. 21, 17; Chro. 5, 1.233

As the notations indicate, these provisions were taken from the Boolss of Deuteronomy and Numbers. While the Body of Liberties modified these, both by making the division turn on intestacy and by adding the provision about the coparceny of the daughters, the similarity between the proposed code and the law actually adopted is striking.

The "Judicialls", with their chapter and verse citations to the Books of Moses, cannot explain the Plymouth inheritance scheme which had adopted the same principles of descent at least three years before the colony of Massachusetts Bay was founded. The law of the former may therefore have influenced the latter. At the same time, the scheme of equal descent to children and a double portion to the eldest son is

230. The general thesis that law in New England was mainly Biblieal has buen argued by Reinsch, English Common Law in the Early American Colonics in 1 Seust

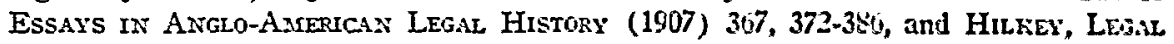
Developarent in Colonial MLassachusetts, $1630-1686$ (1910) 5 , 66 ff., 144. The view has not received much support. Later studies have shown a surprising amount of English local custom and common law in use. It is interesting to note that the Bible is frequently cited in English cases in the sixteenth and seventeenth centuries. See Bradley v. Banks, 1 Bulstr. 141, 142, S0 E. R. 834, 835 (K. B. 1611); Sherborn v. Lewis, Gouldsborough 120,123, 75 E. R. 1037, 1038 (Q. B. 1601); Ratcliff's Case, 3 Co. Rep. 373, 403, 76 E. R. 713, 726 (Q. B. 1592); Reniger v. Fogossa, 1 Plow. 1, 8, 75 E R. 1, 12 (K. B. 1551). Cf. Winfield, Chief Soutaces of Exglish Legall History (1925) 146.

231. 1 Keconds of MAss. (1853) 174. See also id. 175: "\& where there is noe law, then as neere the lawes of God as they can."

232. 1 Hutchinson Papers (Prince Soc, 1865) 181-205. Cf. Ford, Meses his Jisdicialls in 16 Mass. Hist. Soc. Proc. 2d ser. (1902) 274; Calder, Joln Collon's "Moses His Judicials" in $2 S$ MLass. Col. Soc. Trans (1935) St.

233. 1 Hutchinson PAPERS, supra note 232, at 191. 
sufficiently unusual so that the Plymouth law may in turn have been based on the Mosaic code. The strong Calvinistic leanings which infected the social and religious beliefs of the Pilgrims lend support to such a theory. Although evidence fails us, the fact remains that the Plymouth settlers, like those of Massachusetts Bay, were thoroughly acquainted with the Old Testament ${ }^{234}$ and with Calvin's writings. ${ }^{205}$ In fact Calvin had written a sermion, as well as comments, on Detuteronomy XXI, in which the Hebrew law of descent was discussed. ${ }^{236}$ Although Calvin's own scheme of intestate succession exists only in imperfect draft form, ${ }^{297}$ the law of Geneva, with which the Pilgrims seem to have had some acquaintance, followed a scheme of divisible descent. ${ }^{238}$

Yet, except for these two general characteristics, equality of descent and the double portion, the Massachusetts law of descent was not the Mosaic law of descent. For example, under the Hebrew law, daughters were excluded from the inheritance as long as there were either sons or any descendants from sons, ${ }^{230}$ whereas under the Massachusetts intestacy law daughters often took equally with sons. ${ }^{240}$ Again, if a son died without issue, his inheritance under Hebrew law never went to his mother; she and her ancestors were completely excluded. ${ }^{241}$ Yet there is at least one case in the Essex records where mother and father both shared in a deceased son's estate. ${ }^{242}$ Or again, by Hebrew law a grandchild of a deceased eldest son would never take a double portion, ${ }^{243}$ whereas in at least one case in Massachusetts he seems to have done so. ${ }^{244}$ Lastly, according to Hebrew law, an eldest son could receive a double portion only from his father, and never from his mother; ;45

234. Many leading men in the colony were seriously engaged in Hebrew studies and had a profound reverence for Hebrew. See Newman, Jewish Influence on Cunstian Reforar Movements (1925) 635-645. The Jewish law of descent was also well known in England in the seventeenth century. For example, see RoBInson, Gavelkind (1897) 12-13; Selden, De Successionibus in Bona Defincti ad Leges Ebracorum in 2 Orens (1726) cc. 5-8, 12, 13. Selden's exposition of the Jewish law of succession is based on a thorough study of the sources and of Rabbinical interpretations.

235. For example, a copy of Calvin's Institutes was in the library of Miles Standish. 5 New England Histor. and Gen. Reg. (1851) 337.

236. 27 Calvin, Opera (1864-1900) 663-676. See also 24 id. at 709-710; 25 id. at 310-311.

237. 10 id. at 133. For Calvin's influence on the law, see generally BoHATEc, CALviN UND DAs RECHT (1934).

238. Flamkmer, Le Droit Civil de Genève (1875) 17-18.

239. Selden, supra note 234 , at c. 8; Hale, History of the Common Law (1779) 243.

240. For references, see note 93 supra.

241. SeLden, supra note 234, at c. 12; HAlE, op. cit. supra note 239, at 244.

242. 1 Essex Prob. Records (1916) 57-58, 62, $201 ; 2$ id. at 94.

243. SELDEN, supra note 234, at c. 6-7; HALE, op. cit. supra note 239, at 245.

244. 1 Essex PROB. ReCORDS (1916) 395.

245. SELDEN, supra note 234 , at c. 6 . 
yet the Body of Liberties and the Act of 1649 say that when parcuts die intestate, the eldest shall have a double portion. ${ }^{246}$ This is borne out in several Essex cases, where the eldest son took a double portion from an intestate mother. ${ }^{247}$ In short, we can go no further than to say that the notion of equality of shares, with a double portion reserved to the eldest son, may easily have been based on similar features in the Hebrew law of inheritance as laid down in the Books of Deuteronomy and Numbers. The colonists certainly did not attempt to re-enact the detailed rules of the Hebrew law.

Prominent among other ideas which may have played a significant part in shaping the rules of partible descent was the notion of equality, a strong one among the settlers of both Plymouth and Massachusetts Bay. In part this was a result of theories of natural law and equality of rights with which the colonists were deeply imbued. ${ }^{\text {.ts }}$ Thus, John Robinson had said, "we are not over one another, but with one another." ${ }^{49}$ An early town record of Lancaster, Massachusetts, speaks of "that Equallitie which is the rule of God." 250 The idea found expression, for example, in the early allotments of land. In Plymouth the land was allotted according to the numbers in a family, each person thus being thought entitled to an equal share. ${ }^{201}$ Equality in economic status was sought to be maintained by limitations on alienations, and by even distribution of common obligations, such as the burden of taxation and the care of fences and highways. ${ }^{232}$ Quite apart from social theory, these ideas were rooted in a long experience in equality in the sharing of obligations and duties in the routine of English agricultural life which they knew so well. The physical appearance as well as the organization of the New England towns afford striking resemblances to those of the villages and manors of seventeenth century England. It is hard not to conclude that much of the local English agricultural system, carrying with it implicitly the idea of equality, was imported to this country.

246. MAass. CoL. LAws 1660-1672 (18\$9) 51 , c. $\$ 1$; 201, c. 3.

247. 1 Essex Prob. Records (1916) 57-58, 62, 201; 2 id. at 94.

24S. 1 Osgood, The Alserican Colonies in the Seventeeniti Centum (1904) 425.

249. Quoted in Pound, The Spinit of the Commion Law (1921) 42-43. In his sermon in 1621, at New Plymouth, Cushman spoke out strongly against inequality; he finishsd saying, "Did not Satan, who was not content to keep that equal state with his fellows, but would set his throne above the stars?" Quoted in 1 Branforo, Histosi of PLysoutr Plantation (1912) 300, $\mathrm{n}$.

250. 1 HURD, History of WORCester County (1SS9) 6.

251. 1 Bradford, History of Plyaroute Plintition (1912) 299-300. For other instances, see Akagr, The Town Proprietors of the New Ersglamd Colonirs (1924) 107-108; Andrews, Die Stadt in Nett-England (1893-94) 2 Zeltsennfr Für SocanLUND WIRTHSCEAFTSGESHICHTE 103, 224.

252. Andrews, supra note 121 , at $434-435$.

253. See Mifaclear, Early New Exgland Towns (1908) 81 ff.; 1 Oscood, of. cit. suspra note 248 , at 426 . 
At the same time many of the settlers had keenly felt the effects of the inequalities of the English land system which became so apparent in the accumulations of land by a few in the inclosure movement. ${ }^{254}$ Even in the England of that day there was criticism of the inequalities of primogeniture and the unfairness to younger sons. ${ }^{255}$

It seems to have been apparent to the colonists that primogeniture was ill adapted to conditions in New England. It would have encouraged the growth of accumulated estates, which they had learned to distrust. It would also have meant the impoverishment of younger sons who, deprived of a share in their family's lands, would have had no means of support in a frontier community. It would have meant the depletion of the population on which the very success of the colony depended. These matters are expressly recognized in the preamble to the section dealing with intestates' estates in the Act of 1692:

Whereas estates in these plantations do consist chiefly of lands, which have been subdued and brought to improvement by the industry and labour of the proprietors, with the assistance of their children, the younger children generally having been longest and most serviceable unto their parents in that behalf, who have not personal estate to give out unto them in portions, or otherwise to recompense their labours. . . .250

It is apparent that there was much sense in applying the same rules to realty and personalty. Land and houses in the beginning were the chief form of property, ${ }^{257}$ and there was little else for a man to leave to his children. If one son had received the land, there would be nothing for the others. The alternative of seeking work in the towns, as in England, would not be possible in sparsely settled communities. Similar reasons might explain why the County Courts should have varied portions according to need, or allotted to the widow more than her mere dower. Such reasons, too, were pressed by counsel in the arguments before the Privy Council in Phillips v. Savage. ${ }^{268}$ The foundation and growth of the colony, it was said, depended on equality of descent, "for

254. This was particularly true of the Plymouth colonists. Haskins, The Beginnings of the Recording System in Massachusetts (1941) 21 B. U. L. Rev. 281, 299-300.

255. Page, Jus Fratrum, The Law of Brethren (1638); Northtonus, The Younger Brothers Advocate (1655). In the latter, many of the arguments in favor of partible descent are drawn from Mosaic law. Typical is the statement, "So that I cannot see, but that a more equall division, than is generally practised with us amongst brethrell, is more agreable to scripture, right, reason, naturell justice, and no prejudice to the flourishing condition of a Nation, and true happiness of a Commonwealth." Id. at 15.

256. The Charter and General Laws of the Colony and Province of MassaCHUSETTS BAY (1814) 230.

257. This would be less true of Massachusetts Bay than of Plymouth. The inventories in the former show fairly sizeable personal estates.

258. See note 125 supra. 
the whole estate consists in lands, stock, buildings, and such other improvement." ${ }^{259}$ The personal estates were insufficient provision and recompense for the long labor and industry of younger children, in subduing and improving the settlements of their ancestors. "If they were to receive no share at all of those lands which they themselves have cultivated, all future culture must cease, and the unsubdued part of the Colony eternally remain, as it is, a wilderness, and younger children must rove about the world for bread, the Province be depopulated, and so the very intentions of the charter destroyed." fore, there seems to have been much in the social and economic conditions in the colony to support the settlers' theories of equality.

The main features of the colonists' background, social and intellectual, can be discerned with some certainty. That the Plymouth settlers had some knowledge of the Dutch law of descent; that they, in common with the Massachusetts colonists, had some acquaintance with customs of partible inheritance in the manors and towns of England, seems highly probable. That both groups entertained theories of law and government which might cause them to adopt the Mosaic scheme of succession seems likewise very probable. Their religious and social theories, together with the environment from which they came, gave them a strong bias in favor of equality of ownership. Economic conditions in a part of the world which was still wilderness must have had much to do with the adoption and the continuance of rules of partible descent. But it is no easy problem to separate these strands of influence. The records show no single answer.

That the Massachusetts law of inheritance was based neither on the Statute of Distribution nor on gavelkind we can be certain. We may therefore begin by again suggesting that the principles of the Massachusetts Bay scheme of partible inheritance were borrowed directly from Plymouth. The latter colony had had ten years of experience on New England shores, and this experience may well have been drawn upon by the sister colony. This is the more likely, given the other instances of inter-colony borrowing which have already been noted. However, even if we accept this hypothesis, the question is hardly advanced, for we are forced to ask in turn why Plymouth adopted partible inheritance. Here the possibility of Dutch influence may not be neglected in view of the similarities of the two schemes of intestate succession. Beyond this was the common background of both groups of colonists in rural and urban England where customs of partible descent were well known. There had also been first-hand acquaintance with the customary distributions of

259. 5 Miass. Hist. Soc. Proc. (1860-1862) 78.

260. Id. at 78 . 
personalty in the ecclesiastical courts. Although neither the Dutch system, nor the ecclesiastical system, nor the local customs of partibility were reproduced exactly, there are nevertheless hints of all of them. There is much reason to suppose that the colonists availed themselves of their cultural heritage in law, just as they did in religion and farming. The social system of colonial New England was first and last English. Many instances of English common law, both substantive and procedural, can be found in the law of colonial Massachusetts in the seventeenth century. ${ }^{261}$ Practices akin to those of the ecclesiastical courts are also found; indeed, the flexibility of probate procedure and the absence of insistence on formalities in wills in contemporary England ${ }^{202}$ bear striking resemblance to features of the Massachusetts law which have been observed. But above all, the similarities between New England practices and customs in the parts of England from which the settlers came are most noticeable. ${ }^{203}$ It is to be remembered that until well on in the seventeenth century there were few professional lawyers in the colony, ${ }^{204}$ and there were few English law books. ${ }^{265}$ In the days before the common law had acquired its universal dominion, local customs and local courts loomed large in the eyes of the average Englishman. It was these that formed the larger part of the legal heritage of the persons who settled New England in the early seventeenth century. It was the half-remembered notions of customs in other lands which, together with the needs of a frontier community, seem to have been of high significance in the early law of the New England colonies.

In stressing such features, we must not forget the significance of the belief that the word of God, as exhibited in the Old Testament, was to the colonists law in a fundamental sense; nor that ideas about equality played a highly important part in their outlook. The Mosaic analogy, because of the double portion, is a particularly tempting source for the intestacy law. Even if it were not the source itself, the passages in the Books of Deuteronomy and Numbers would provide the settlers, as they did John Cotton, with a ready rationalization of the inheritance scheme.

No single "source" can be pointed to without distorting the facts as they were. Professor Goebel has pointed with some acuteness to the

261. See Morris, Massachusetts and the Comnton Lave (1926) 31 AMER. Hist. Rev. 443; Chafee, in 1 Suffolk Countly Records xxx-xxxii, xxxviii; Plucknett, Book Review (1930) 3 New England Quarterly 159. Cf. 4 Records of Mass. (1853) pt. ii, 554555, where in 1673 the question arose as to whether the heir of an intestate might enter by attorney, and a committee was appointed to discover the law of England in the matter. 262. See 3 Holdsworte, History of English Law (1935) 538-539, 541.

263. For further discussion, see Goebel, King's Law and Local Custom in Seventeculh Century New England (1931) 31 CoL. L. Rev. 416, 434 ff.

264. Chafee, in 1 Suffolk County Records xxiii-xxvii.

265. Id. at $\mathrm{xxx}-\mathrm{x} \times \mathrm{x} \times \mathrm{ii}$. 
curious mélange of religious ideas and the remnants of English local customs which pervaded the laws and institutions of Plymouth and Massachusetts Bay. ${ }^{266}$ It seems altogether possible that in the beginnings of the law of partible descent in Massachusetts there may have been some such mixture of custom and ideal. But in the last analysis, the answer is that it proved a wise method of distribution which produced on the whole fair results. Whatever the reasons for its original adoption, its suitability to colonial conditions is why in the long run it survived and became one of the roots of the modern law of intestate division of realty.

We cannot close without pointing out that this study has a wider import than as a chapter in legal history. Stressing as it does the social and intellectual background of the colonists, it takes on significance as a study in survival and adaptation of patterns of thought, habits of life. Important for what light it sheds on the sources of colonial law in general, it further shows the law adapting itself to the needs of the colonists in New England. It reveals the beginnings of an indigenous American law, not overly hampered by tradition, growing up in response to the social and economic conditions of a new civilization.

266. Goebel, King's Law and Local Custom in Secuteculh Century Ncou Englasd (1931) 31 Cor. L. Rev. 416, 447-448. 